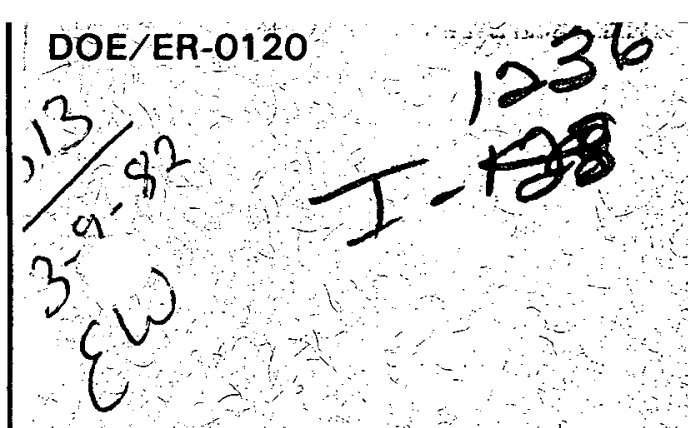

\title{
Summary Outline of DOE Geoscience and Geoscience - Related Research
}

Published: February 1982

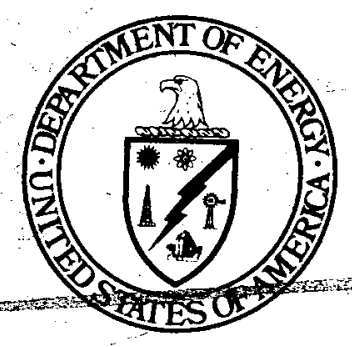

NOTICE

PORTICNS OF THIS REPORT ARE ILLEGIBLE. It has bepr yomecised from the best available cony io rom the broadest possible avaif ahility.

\section{U.S. Department of Energy Office of Basic Energy Sciences Geosciences Program}




\section{DISCLAIMER}

Portions of this document may be illegible in electronic image products. Images are produced from the best available original document. 


\section{DISCLAIMER}

"This report was prepared as an account of work sponsored by an agency of the United States Government. Neither the United States Government nor any agency thereof, nor any of their employees, makes any watranty express or implied, or assumes any legal liability or responsibility for the accuracy, completeness, or usefulness of any information, apparatus, product, or process disclosed, or represents that its use would not infringe privately owned rights. Reference herein to any specific commercial product, process, or service by trade name, trademark, manufacturer, or otherwise, does not necessarily constitute or imply its endorsement, recommendation, or favoring by the United States Government-or any agency thereof. The vièws and opinions of authors expressèd herein do not necessarily state or reflect those of the United States Government or any agency thereof:"

This report has been reproduced directly from the best available copy.

Available from the National Technical Information Service, U. S. Department of Commerce, Springfield, Virginia 22161 .

Price: Printed Copy A06
Microfiche A01

Codes are used for pricing all publications. The code is determined by the number of pages in the publication. Information pertaining to the pricing codes can be found in the current issues of the following publications, which are generally available in most libraries: Energy Research Abstracts, (ERA); Gövernment Reports Announcements and Index (GRA and I); Scientific and Technical Abstract Reports (STAR); and publication, NTIS-PR.360 available from (NTIS) at the above address. 


\section{Summary Outline of DOE Geoscience and Geoscience - Related Research}

Published: February 1982
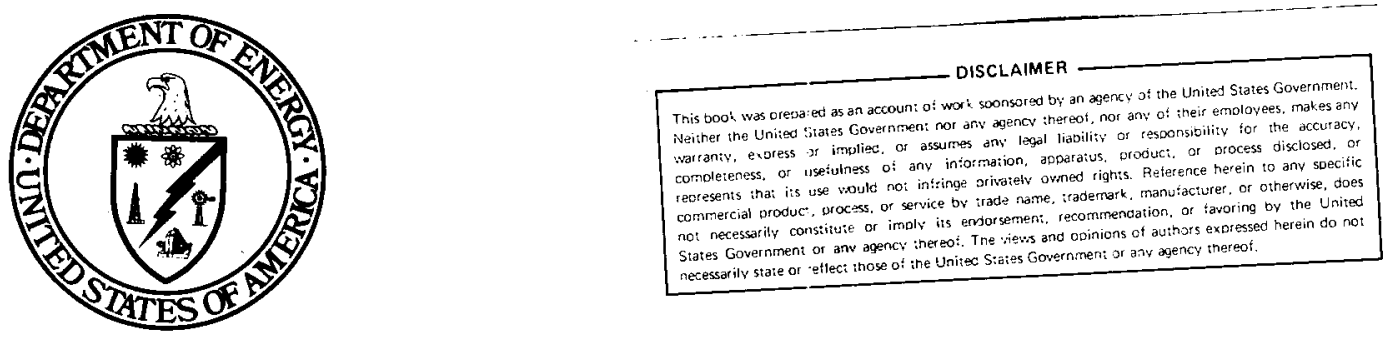

\section{U.S. Department of Energy}

Office of Basic Enèrgy Sciences

Geosciences Program

Washington, DC 20545 


\section{CONTENTS}

Foreword

Geosciences Working Group 1981

Geosciences Working Group $1982 \quad$ iii

Energy Research (ER)

Office of Basic Energy Sclences $\quad$ ER-1

Division of Engineering, Mathematical \& Geosciences ER-2 Division of Carbon Dioxide Research ER-9

office of Health and Environmental Research Division of Ecological Research

ER-13

Conservation and Renewable Energy (CE)

Office of Energy Systems Research

Division of Energy Storage Technology CE-1

Office of Renewable Technology

Division of Geothermal and Hydropower Technology CE-3

Fossil Energy (FE)

Office of 0il, Gas and Shale

Division of $0 i 1$

FE-1

Division of Gas

FE-10

Division of Oil Shale

$\mathrm{FE}-12$

Nuclear Energy (NE) NE-1

Nuclear Reactor Programs

Plans and Analysis

Nuclear Waste Management and Fuel Cycle Programs

Office of Waste Isolation

(1)

Office of Uranium Enrichment and Assessment

$\mathrm{NE}-2$

$\mathrm{NE}-4$

NE-39

Defense Programs (DP)

$\mathrm{DP}-1$

Office of Military Application

$\mathrm{DP}-2$ 


\title{
FOREWORD
}

This document is being issued during a period of rapid change, both technically and organizationally, in the Department of Energy. Nevertheless, we feel that the information contained herein will be useful for those concerned with the Geosciences aspects of the U. S. Energy Program.

Research is supported principally at National Laboratories and Universities. The amount of University support during the time covered by this report was $\$ 16,000,000$.

\author{
$\sigma \Omega$ \\ George A. Kolstad, Chairman \\ DOE Geosciences Working Group \\ $23.3-5832.2$
}


$1980-81$

Geosciences Working Group

\author{
Major Randy Davis \\ Dr. David H. Duke \\ Dr. Herman L. Finke \\ Dr. Robert A. Gray \\ Dr. Charlene Hall \\ Dr. James R. Hill \\ Cdr. Frank W. Hughes \\ Dr. Cyrus K1ingsberg \\ Dr. George A. Kolstad \\ Dr. Thomas P. Longo \\ Dr. Ira Mayfield \\ Dr. Darrell Munsen \\ Dr. John Salisbury \\ Dr. Robert Sharp \\ Dr. George L. Sherwood \\ Dr. Yo T. Song \\ Dr. Herbert Wang \\ Dr. Frank J. Wobber
}


1981-82

Geosciences Working Group

MEMBERS

Dr. Charles Bufe

Dr. Pau1 J. Ebert

Dr. Edward Ferrero

Dr. James R. Hill

Dr. Cyrus Klingsberg

Dr. George A. Kolstad

Dr. David Lombard

Dr. Thomas P. Longo

Dr. Larry Luhrs

Dr. John Patterson

Dr. Robert K. Pitman

Dr. Edward Schreiber

Dr. George L. Sherwood

Dr. Harry W. Smedes

Dr. Yo T. Song

Dr. Harold E. Thomas

Dr. Frank J. Wobber
PHONE NO. *

252-5334

353-5342

353-2877

353-5626

353-3919

353-5822

252-8670

353-3791

353-2744

353-5173

353-5956

353-5822

353-5845

353-3599

353-5350

353-2707

353-5549

* Area code 301 for 353 prefix Area code 202 for 252 prefix 
The Office of Basic Energy Sciences (OBES) supports long-range, basic research in those areas of the geosciences which are relevant to the nation's energy needs. The scientific objective of the Geoscience program is to develop a quantitative and predictive understanding of geological, geophysical and geochemical structures and processes in the solid earth and in solar-terrestrial relationships. This understanding is to assure an effective knowledge base for energy resource recognition, evaluation and utilization in an environmentally acceptable manner. The work is carried out primarily in DOE laboratories and in universities, although some is conducted by other Federal agencies and by the National Academy of Sciences. Principal areas of interest include:

1. Geology, Geophysics and Earth Dynamics - large-scale earth movements; evolution of geologic structures; properties of earth materials, rock flow, fracture and failure; Continental Scientific Drilling Program.

2. Geochemistry - thermochemical properties of geologic materials; static rock-water interactions; organic geochemistry; geochemical migration.

3. Energy Resource Recognition, Evaluation and Utilization - resource definition and utilization; reservoir dynamics and modeling; magma energy resources.

4. Hydrologic and Marine Sciences.

5. Solar-Terrestrial/Atmospheric Interactions - magnetospheric physics and chemistry; upper atmosphere chemistry and physics; solar radiation. 


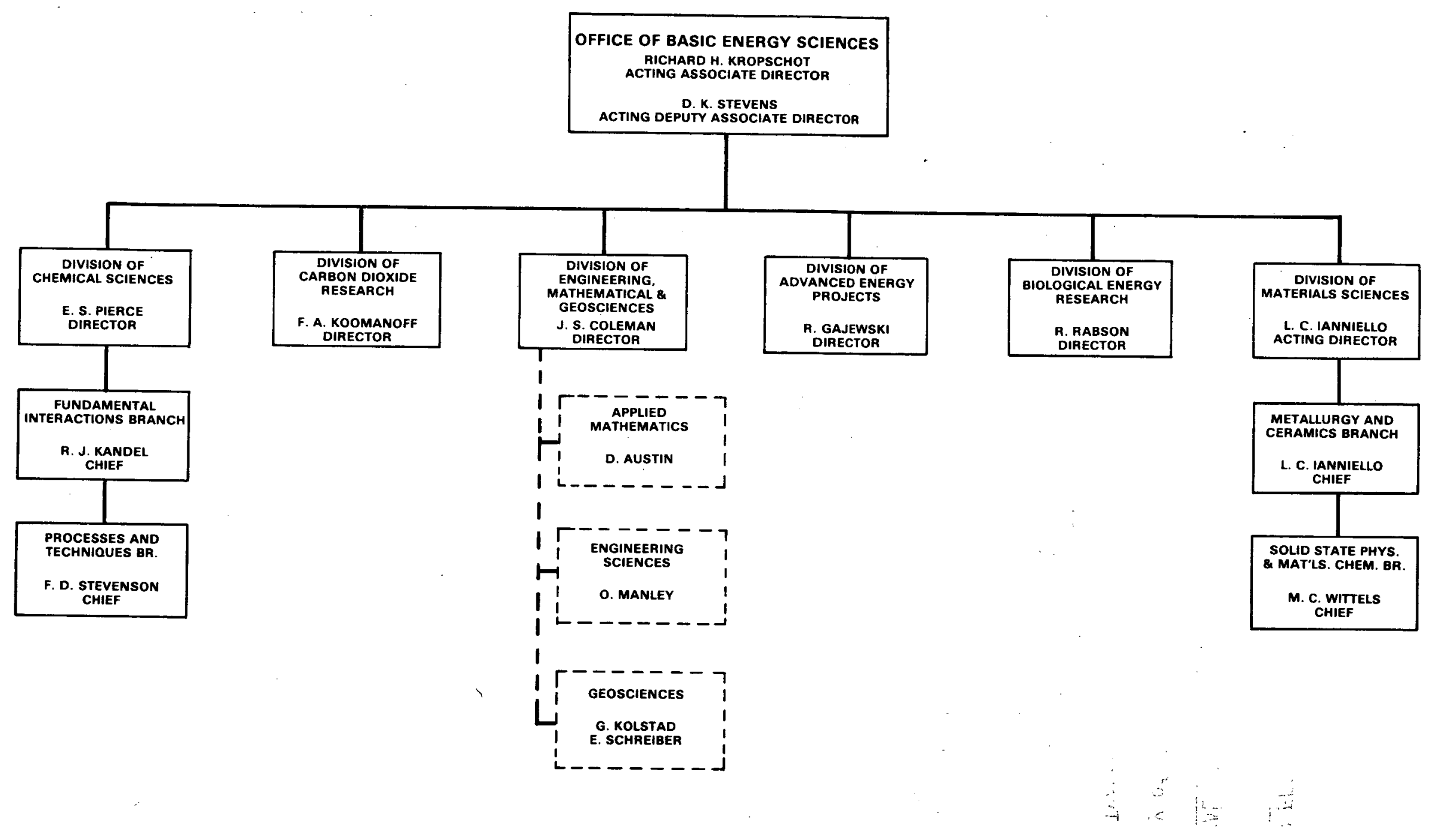


OFFICE OF BASIC ENERGY SCIENCES

DOE GEOSCIENCE PROGRAl.

(Operating Costs, Thousands)

LABORATORY AND EFFORT

PRINCIPAL INVESTIGATOR(S)

FY 80

ARGONNE NATIONAL LABORATORY

Thermochemistry of Geothermal Materials

Cafasso/0'Hare

100

Trace Element Transport

Seitz/Couture

90

Migration of Heavy Element Chemical

Fields/Fried

50

Species in Geologic Strata

LOS ALAMOS SCIENTIFIC NATIONAL LABORATORY

Geophysics \& Geology Base Program

Riecker

770

Continental Scientific Drilling Prooram - Heiken/Goff

Curatorial Needs Assessment

Continental Scientific Drilling Program - Goff

Comparative Site Assessment (Geology)

Geochemical Research

Vidale/Holley/Herrick

350

Element Migration and Fixation in Rocks

Vidale/Duffy

50

Energy Conversion \& Transport in Space Plasmas

Feldman/Asbridge/Bame/Gosling

80

Study of the Electrodynamical Aspects of the Solar Wind-Magnetosphere Interaction

Hones

LAWRENCE BERKELEY LABORATORY

Deep Electromagnetic Sounding of the Crust Morrison 60

Thermodynamics of High Temperature Brines Pitzer 105

Reservoir Dynamics

Tsang

155

Properties \& Behavior of Rock-Fluid

Somerton

90 Systems

Thermodynamic Properties of Silicate Liq- Carmichael uids 
OFFICE OF BASIC ENERGY SCIENCES

DOE GEOSCIENCE PROGRAM

(Operating Costs; Thousands)

LABORATORY AND EFFORT

LAWRENCE BERKELEY LABORATORY (CONT'D)

Rock-Water Interactions

Chemical Transport in Natural Systems

Continental Scientific Drilling Program Comparative Site Assessment (Geochemistry)

Feasibility of Shear Wave Generators for Deep Crustal Studies

Aqueous Solutions Data Base

LAWRENCE LIVERMORE NATIONAL LABORATORY

Diffusion in Earth Materials

Determination of Seismic Q With Depth

Underground Imaging

Thermodynamics, Kinetics \& Transport

in Aqueous Electrolyte Solutions

Rock Mechanics

Continental Scientific Drilling Program Information and Data Management

Continental Scientific Drilling Program Comparative Site Assessment (Geophysics)
PRINCIPAL INUESTIGATOR(s)

Fy 80

Apps

100

Carnahan

iot

150

White

60

Coen/Morrison

90

Phillips

75

Condit/Piwinskii

70

Patton/Nakanishi

170

Duba/Lyt le

140

Miller/Rard

190

Heuze

100

Howard

180

Kasameyer

60

Mesmer/Naney

190

Physical Chemistry of Geotherma? So1 utions and Materials

Dickson
Investigations of Aqueous Media with Constituents of Natural Formations 


\section{OFFICE OF BASIC ENERGY SCIENCES \\ DOE GEOSCIENCE PROGRAM \\ (Operating Costs, Thousands)}

LABORATORY AND-EFFORT

Insolation and Aeronomy Studies

Remote Sensing: Geoscience Data

Analysis Methodology

Trace Constituent Sorption and Migration in Geologic Media

Chemical Migration by Contact Metamorphism in Granite-Carbonate Rocks

SANDIA NATIONAL LABORATORIES--ALBUQUERQUE

Magma Energy Research

Continental Scientific Drilling Program-Magma Research

Continental Scientific Drilling Program-Comparative Site Assessment (Energy Transport)

Continental Scientific Drilling Program-- Jones/Hardee/Luth Coordination

Modeling of Geodetic Crustal Strain Data
Colp/Gerl ach/Hardee

900

PRINCIPAL INUESTIGATOR(S)

Stokes/Michalsky/Smi th/Kleckner

Foote/Blair

95

$\operatorname{Ra} i$

90

LauT

80

Luth/Hardee/Gerlach

120

Hardee/Luth

60

25

Rundle/Passman

60 
OFFICE OF BASIC ENERGY SCIENCES

DOE GEOSCIENCE PROGRAM

(Operating Costs, Thousands)

CONTRACT RESEARCH

University of Alaska: Magnetic Field Annihilation Process in Magnetosphere and Some Geotechnical Applications

University of Alaska: Operation of a Telemetered Seismic Network on the Alaskan Peninsula

University of Arizona: Solar Variability Observed Through Changes in Solar Figure and Mean Density

Arizona State University: Silicate, Alu- Navrotsky minosilicate and Borosilicate Glasses and Melts - Thermochemical Studies by High Temperature Calorimetry

Aspen Institute for Humanistic Studies: Roberts Mechanisms for Effects of Solar Variability on Weather

Brown University: Application of Natural Hermance Electromagnetic Field Methods

University of California at Berkeley: Reynolds Isotopic Studies on Rare Gases in Terrestrial Samples and in Natural Nucleosynthes is

University of Cal ifornia at Los Angeles: Relationship of Rock Physics and Petrology to Geothermal Energy Technology

University of California at Los Angeles: Compressibility Measurements

University of Chicago: Depth to and Concentrations of Water in Large Bodies of Silicic Magma

Columbia University: A Comprehensive Study of the Seismotectonics of the Eastern Aleutian Arc and Associated Volcanic Systems

Columbia University: Rock Fracture Permeability at High Pressure and Temperature
PRINCIPAL INVESTIGATOR (S)

Akasofu

Fy 80

84.3

86.6

90.6

35

70.5

140

144.1

Anderson/Warren

107

Kennedy

72

Anderson

54

Sykes/Jacobs/Davies

311.8

Scholz/Engelder

140 
OFFICE OF BASIC ENERGY SCIENCES

DOE GEOSCIENICE PROGRAM

(Operating Costs, Thousands)

CONTRACT RESEARCH

\section{$12 i \mathrm{~s}$}

Indianapolis Center for Advanced Research: Computerized Underground Image Reconstruction

Massachusetts Institute of Technology: Seismology of Crack Formation in $\mathrm{Hy}$-draulic Rock Fracture and Natural Geotherma] Environments

Massachusetts Institute of Technology: Microcrack Technology

National Academy of Sciences/National Research Council: Studies in Geophysics

National Academy of Sciences/National Research Council: U. S. Geodynamics Committee

National Academy of Sciences/National Research Council: Continental Scientific Drilling Committee

National Academy of Sciences/National Research Council: Committee on Seismology

Pennsylvania State University: The Effect of Strain Rate and Stress Corrosion on Long-Term Strength of Crystalline Rocks

Rice University: Alteration of Organic Matter and Generation of Petroleum During Burial Diagenesis of Carbonate Sediments

Stanford University: Fluid Permeability, Porosity and Physical Properties of Crustal Rocks/A Study of Seismic Velocity Variations and Attenuation to Delineate Geothermal Reservoirs

State University of New York at Story Brook: Chemical Migration by Contact Metamorphism in GraniteCarbonate Rocks

\section{PRINCIPAL INUESTIGATORS (S)}

Fy 80

Dines

Aki

Simmons

Hart

Hart

20

Hart 60

Berg

Martin

Baker

15.6

Nur/Kovach

Papike 59.1 


\section{OFFICE OF BASIC ENERGY SCIENCES}

DOE GEOSCIENCE PROGRAM

(Operating Costs, Thousands)

CONTRACT RESEARCH

TEXAS A\&M: Mechanical and Transport Properties of Rocks at High Temperatures and Pressures

University of Tulsa: Stability of Natura 1 Gas in Deep Subsurface

Woods Hole Oceanographic Institution: Organic Geochemistry of Continental Margin Sediments
PRINCIPAL INUESTIGATOR(S)

Friedman/Carter/Johnson/Handin

Barker

Hunt

Gordon

Yale University: Experimental Study of Opening Mode Crack Growth in Rock
FY 80

208.5

NFE *

140.7

3.6

CONTRACT RESEARCH TOTAL GRAND TOTAL
$\$ 2402.8$

$\$ 7977.8$

* No Fund Extension 
$\mathrm{CO}_{2}$ and Climate Division

Carbon dioxide research provides the scientific basis for the development of a national and global energy policy for the carbon dioxide issue through comprehensive investigation of the global carbon cylce, climate impact of carbon dioxide, environmental impacts of a climate change, societal consequences of an environmental change, and measures needed for ameliorating or adapting to the undesirable consequences from the future use of fossil fuels.

Integrated geoscience research on the $\mathrm{CO}_{2}$ issue includes observation of atmospheric $\mathrm{CO}_{2}$, fluxes of $\mathrm{CO}_{2}$ among major reservoirs of the earth (atmosphere, ocean, land), and documentation of $\mathrm{CO}_{2}$ of ice cores. The effect of $\mathrm{CO}_{2}$ on climate is investigated with the aid of climate models and paleoclimate data. These approaches make use of geoscience data such as radiation flux, heat capacity and transport, cloud-ice-land albedo, and atmospheric circulation. Research on effects of climate change on the physical environment includes investigations of glaciology, permafrost, and ocean circulation. Integrated studies also include C02-induced effects on meteorology, hydrology and water resources. 
Lamont-Doherty Geological Observatory

Geophysical Institute - Univ. of Alaska

Lamont-Doherty Geo'ingical Observatory Woods Hole Oceanographic Institution Scripps Institution of Oceanography University of Miami

Argonne National Laboratory

Scripps Institution of Oceanography

University of Bern (Switzerland)

Pacific Northwest Laboratory

University of Washington

Lamont-Doherty Geological Observatory

Lawrence Berkeley Laboratory

Scripps Institution of Oceanography

Oregon State University

Oak Ridge National Laboratory
Coral Growth Rings and the Temporal History of Nuclear ${ }^{14} \mathrm{C} / \mathrm{C}$ and ${ }^{96} \mathrm{Sr} / \mathrm{Sr}$ in the Surface Ocean

Carbon Dioxide in Arctic and Sub-Artic Regions

North Atlantic Study of the Transient

Tracers in the Ocean Program (NAS/TTO)

$\mathrm{CO}_{2}$ Flux Verification Studies

A Study of the Abundance of Carbon Dioxide in the Atmosphere and It's Exchange with the Ocean

Reconstruction of the History of the Atmospheric $\mathrm{CO}_{2}$ Content and $13 \mathrm{C} / 12 \mathrm{C}$ Ratio by Ice Core Analysis

Atmospheric $\mathrm{CO}_{2}$ Abundance - An Archival Study of Spectroscopic Data

Geochemical Determination of Biospheric $\mathrm{CO}_{2}$ Fluxes to the Atmosphere

141

150

Investigation of the Surface Water $\mathrm{pCO}_{2}$ in the Equatorial Pacific Ocean

59

Determination of Atmospheric $\mathrm{CO}_{2}-\mathrm{O}_{2} / \mathrm{N}_{2}$

Carbon Dioxide Measurements in the Equatorial Pacific

Research on the Dynamics of the Climate 
Lawrence Livermore National Laboratory University of Michigan

National Center for Atmospheric Research

\section{Brown University}

University of East Anglia (England).

Oregon State University

University of Washington

Argonne National Laboratory

New York University

Scripps Institution of Oceanography Oak Ridge National Laboratory

Lamont-Doherty Geological Observatory Lawrence Berkeley Laboratory

University of Arizona

University of Arizona

University of Toronto (Canada)

Weather Service Nuclear Support Office, NOAA
Carbon Dioxide Effects Research

385

630

600

A Coupled Carbon Dioxide and Water Vapor Transport Radiation Model

30

30

30

Enhanced Research Program on the Long-Range Climatic Effects of Increasing Atmospheric $\mathrm{CO}_{2}$

Global Temperature Patterns 6000 Years Ago

Geographical Patters of $\mathrm{Climatic}$ Change

200

160

On the Increase of Total $\mathrm{CO}_{2}$ in the World Oceans

Deep Ocean Tracer Release Experiment, DOTREX

${ }^{14} \mathrm{CO}_{2}$ Tracer for Fossil Fuel

Geochemical and Geophysical Models of the Fossil Fuel Carbon Dioxide Problem

Development of a Laser Detection System for Argon 39 and Application to Oceanographic Mixing Studies

Variations in Arctic Cloud Cover in Summer

The Role of the Carbonaceous Aerosol in $\mathrm{Cli}$ mate Modification

Dendrochronology of Bristlecone Pine

Accurate Determination of $13 \mathrm{C} / 12 \mathrm{C}$ in $\mathrm{CO}_{2}$ of Past Atmospheres from $13 \mathrm{C} /{ }^{12} \mathrm{C}$ in Tree Rings

By Removal of Climatic Interferences

59

Storage of Non-Living Organic Carbon in Boreal and Arctic Zones

Atmospheric Transport Models

$\begin{array}{rr}52 & 52 \\ 125 & 125 \\ 45 & 45 \\ & \\ 56 & 56 \\ 46 & 46 \\ 50 & 50\end{array}$




\begin{tabular}{ccc} 
FY 80 & FY 81 & FY 82 \\
150 & 164 & 150 \\
160 & 110 & 160 \\
\hline 4010 & $\frac{5840}{4777}$
\end{tabular}

Massachusetts Institute of Technology

University of Miami
Climate Fluctuations, Volcanic Aerosol and Carbon Dioxide

Climate Effects of Atmospheric Transport and Transformation of Hydrogenous Species 


\title{
OFFICE OF HEALTH AND ENVIRONMENTAL RESEARCH
}

\author{
ECOLOGICAL RESEARCH DIVISION
}

\author{
GEOSCIENCES RESEARCH
}

\begin{abstract}
The Office of Health and Environmental Research supports geosciences research in the Ecological Research Division. Since 1950, OHER's mission has been to provide a knowledge base in the basic sciences; and particularly long term environmental and ecological research in all energy technologies. In the past several years, geological and hydrological research had been directed to the transformation and effects of nonnuclear pollutants within ecological systems. OHER gives priority to research on intermediate to long term effects of energy technologies on the environment; technical research that directly supports the requirements of environmental laws is conducted by other agencies.
\end{abstract}

\section{ECOLOGICAL RESEARCH DIVISION}

The objectives of geosciences research within the Ecological Research Division are development of scientific information aimed at anticipating the effects of energy technologies in natural environments, and understanding the environmental changes that result from energy development. Geosciences research in the Ecological Research Division, like other basic research in OHER, is aimed at developing a long term base of knowledge about the effects of new and emerging energy technologies and future energy development. The results of scientific research in the geosciences have proven useful to diverse groups, within the Department of Energy in the solution of intermediate and long term energy issues; other groups including the Department of Interior, National Academy of Sciences, and numerous state agencies commonly draw upon the Division's geosciences publications in nuclear, coal, and other energy sources.

Division projects are interdisciplinary in content; research projects commonly involve the disciplines of geology, ecology, hydrology, marine sciences, chemistry, and biology. Geosciences research is rarely conducted in isolation from other disciplines. For example, the marine environment is the ultimate receiving system for energy wastes; understanding the assimilative capacity of the marine environment might require research in marine processes and the geochemistry of continental shelf sediments.

This interdisciplinary research approach means that geosciences funds are distributed within multidisciplinary research projects; research funds apportioned to geosciences research are detailed in Table I. Geosciences research that is less than $5 \%$ of total funding is not detailed; this additional research commitment to geosciences is estimated to be $\$ 100,000$. 
Approximately $20 \%$ of all research in the Ecological Research Division involves physical oceanography, geology, geochemistry, and hydrology. Additional geological and hydrological research related to the effects of energy-solid waste disposal is expected in FY 82 and FY 83. Aerial and satellite remote sensing is a potentially important research method for ecological studies; it will be tested more extensively in the future to predict and evaluate the long term regional effects of energy technologies on terrestrial ecosystems.

Principal areas of geosciences activity include:

1. Physical 0ceanography - including mixing and circulation of water, distribution of radionuclides and other energy contaminants in ocean water and sediments, the assimilative capacity of marine sediments, marine sediment transport and trace metal studies in the marine environment.

2. Cycling of radionuclides - including research in marine geochemistry and freshwater systems and the transport and movement of radionuclides.

3. Ecosystem modelling - including surface and groundwater systems as receptors of energy pollutants; transport of energy residuals in surface waters; stream and estuarine sedimentation and the hydrology of disturbed lands.

4. Ecological effects of land disturbances, including disposal of energy residuals - the hydrology of disturbed lands, reclamation, soils and sedimentation investigations, geochemistry, and ecological impacts.

Two multidisciplinary research planning activities were completed in FY 80FY 81; a research plan, Solid Wastes from Energy-Producing Technologies (1980) and Status of Health and Environmental Research Related to Solid Wastes from Coal Conversion (1981). 


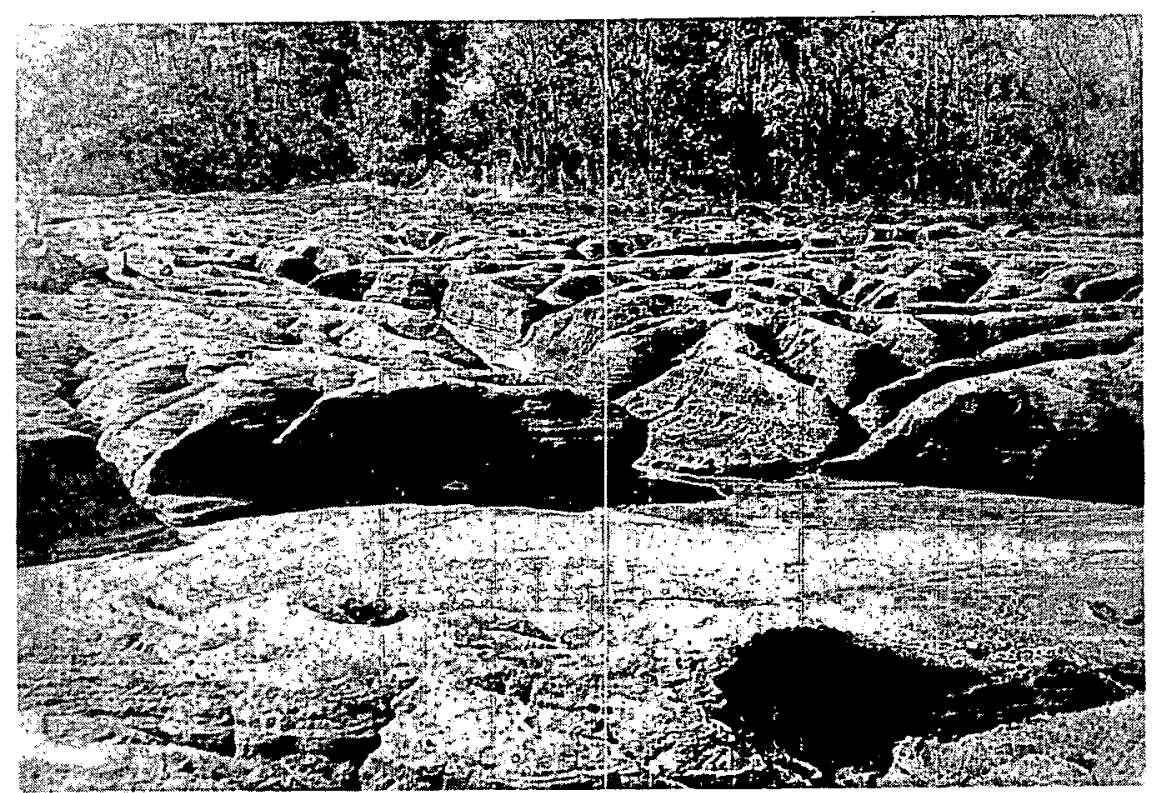

Coal waste disposal site in southern Indiana. Laboratory and field research are carried out at sites such as this one. Long term research related to regional disposal of energy wastes, stabilization and reclamation of waste sites, the mobilization and transport of leachates into groundwater systems, and sedimentation are among the geosciences questions being examined with OHER. 


\section{OFFICE OF HEALTH AND ENVIRONMENTAL RESEARCH}

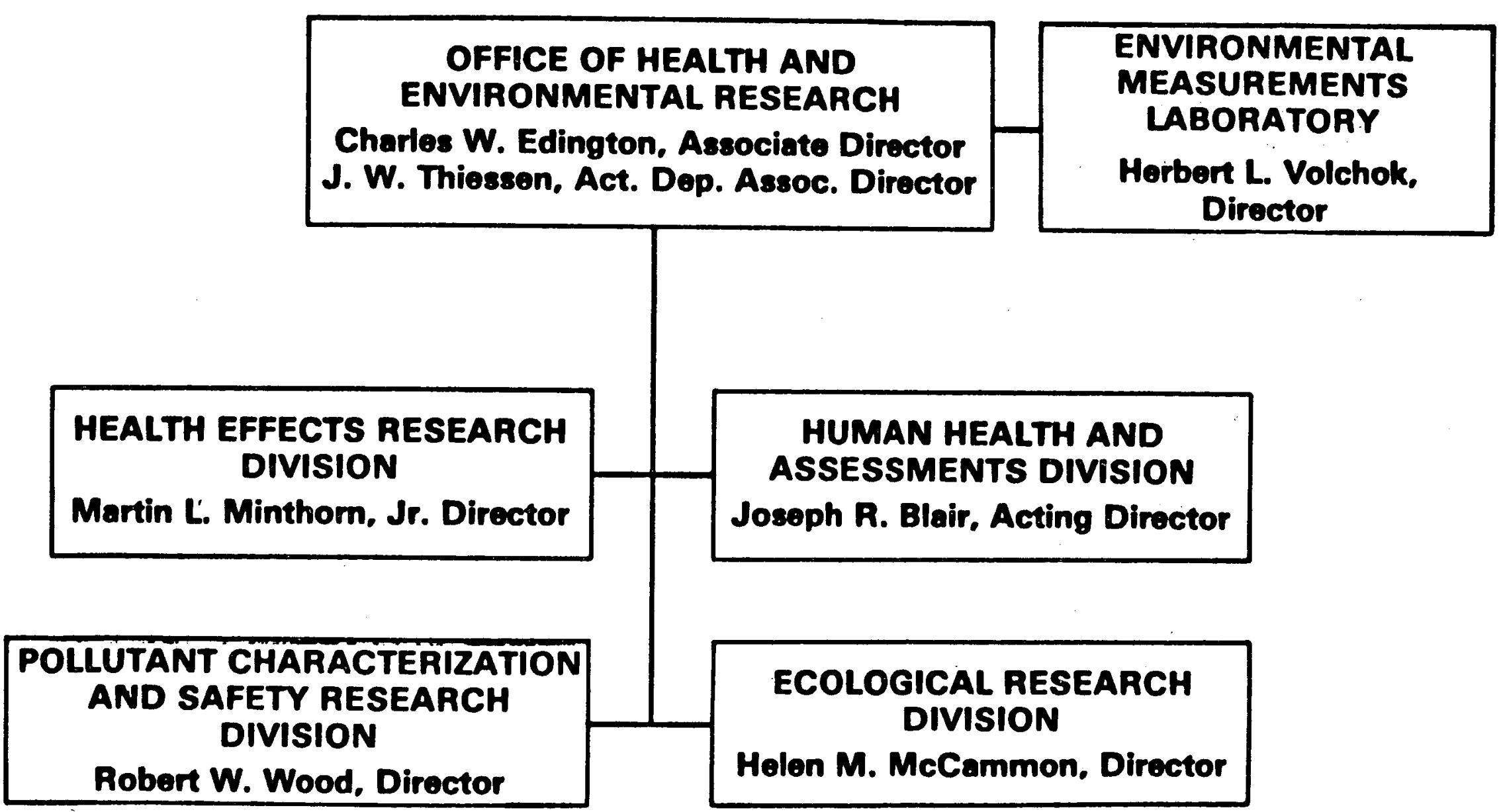




\section{OFFICE OF HEALTH AND ENVIRONMENTAL RESEARCH PROGRAM ORGANIZATION}

HUMAN HEALTH AND ASSESSMENTS

HUMAN HEALTH EFFECTS FROM

ENERGY

GENERATION

OCCUPATIONAL

HEALTH AND

MEDICAL

RESEARCH

BIOMEDICA!

APPLICATIONS

ENVIRONMENTAL

ASSESSMENTS

HEALTH

ASSESSMENTS
HEALTH EFFECTS RESEARCH

CARCINOGENESIS

MUtAgeNESIS

SYSTEMS DAMAGE

(TOXICOLOGY)

GENERAL LIFE

SCIENCES

\author{
ECOLOGICAL \\ RESEARCH \\ TRANSPORT AND \\ CONVERSION OF \\ ENERGY-RELATED \\ POLLUTANTS IN \\ TERRESTRIAL \& \\ AQUATIC \\ ECOSYSTEMS \\ EFFECTS OF \\ ENERGY-RELATED \\ PROCESSES AND \\ POLLUTANTS \\ FUNDAMENTAL \\ ENVIRONMENTAL \\ PROCESSES
}

POLLUTANT CHARACTERIZATION AND SAFETY RESEARCH

ANALYTICAL CHARACTERIZATION

ATMOSPHERIC TRANSPORT AND TRANSFORMATION

PHYSICS \& CHEMISTRY OF POLLUTANT INTERACTIONS

MEASUREMENT SCIENCE

OCCUPATIONAL HEALTH AND SAFETY

EFFECTS OF CLIMATE VARIATION ON THE ENERGY SYSTEM 
OFFICE OF HEALTH AND ENVIRONMENTAL RESEARCH

ECOLOGICAL RESEARCH DIVISION

GLOSCIENCES RLLATED RESEARCH

PHYS ICAL OCEANOGRAPHY

Principal

Laboratory/Contractor

Investigator

FY $1980(\$ 000)$

Columbia Unlversity, Transport and Transfer Rates in the

Waters of the Cont Inental Sheif.

P. Biscaye

(364)

U. of Washington, Pollutant Transport and Sediment Dispersal

In the Washington-Oregon Coastal Zone.

B. Hickey

U. of Miami; She1f Circulation in the South Atlantic

T. Lee

Bight.

Woods Hole Oceanographic Institution, Coastal-Shelf Transport and Diffusion.

G. Csanady

Sk1daway Inst. of Oceanography, Nearshore Transport Processes Affecting the Dilution and Fate of Energy-Related Contaminants.

J. Blanton

Skidaway Inst. of Oceanography, Continental Shelf Processes Affecting the Oceanography of the South Atlantic Bight.

L. Atkinson

North Carolina State U., Continental Shelf Processes Effecting the Oceanography of the South Atlantic Bight.

L. Pletrafesa

Brookhaven National Laboratory, Coasta1 Transport \& Diffusion.

T. Hopkins 
OFFICE OF HEALTII AND FNVIRONMFNTAL RESEARCH

ECOLOGICN. RESEARCH DIVISION

GEOSCIENCES RELATED RESEARCH

CYCLING OF RADIONUCLIDES

Laboratory/Contractor

Principal

Investigator

FY $1980(\$ 000)$

Lawrence Livermore Laboratory, Hydrogeochemistry of

Enewetak Studies on Aquifers.

Buddemeler

Savannah River Laboratory, Distribution and Movement of

Plutonium on Sedimentary Particles in the Savannah River and 1 ts Es tuary.

Hayes

Texas A\&M, Geochemical Behavior of Urantum and plutontum In the Mississippi and Rlo Grande River Estuaries.

$\operatorname{Scot} t$

Columbia University, Plutonium, Ceslum and Uranium Transport and Distribution on Sediments in the Hudson River, its

Watershed and Estuary.

Simpson

Oregon State University, Cycling of Transuranic Radionuclides and Technetium in the Columbia River, its Estuary and the Coastal Shelf.

Beasley

U. of Wisconsin, Chemical Attenuation of Solutes.

Anderson

Yale University, The Fate of Nuc1ides in Natural

Water Systems.

K. Turekian

ORNL, Radionuclide Sources in the Coastal Zone.

Cutsha11

U. of Washington, Chemfcal and Geochemical Studies off the Coast of Washington.

R. Carpenter

U. of Alaska, Transport and Reaction of Heavy Metals in Alaskan Fjord estuaries.

D. Burre11 
OFFICE OF HEAITII AND ENVIRONMINTAL RESEARCH

ECOLOGICAL RESEARCH DIVISION

CEOSCIENCES RELATIED RI:SEARCH

CYCLING OF RADIONUCLIDES, continued.

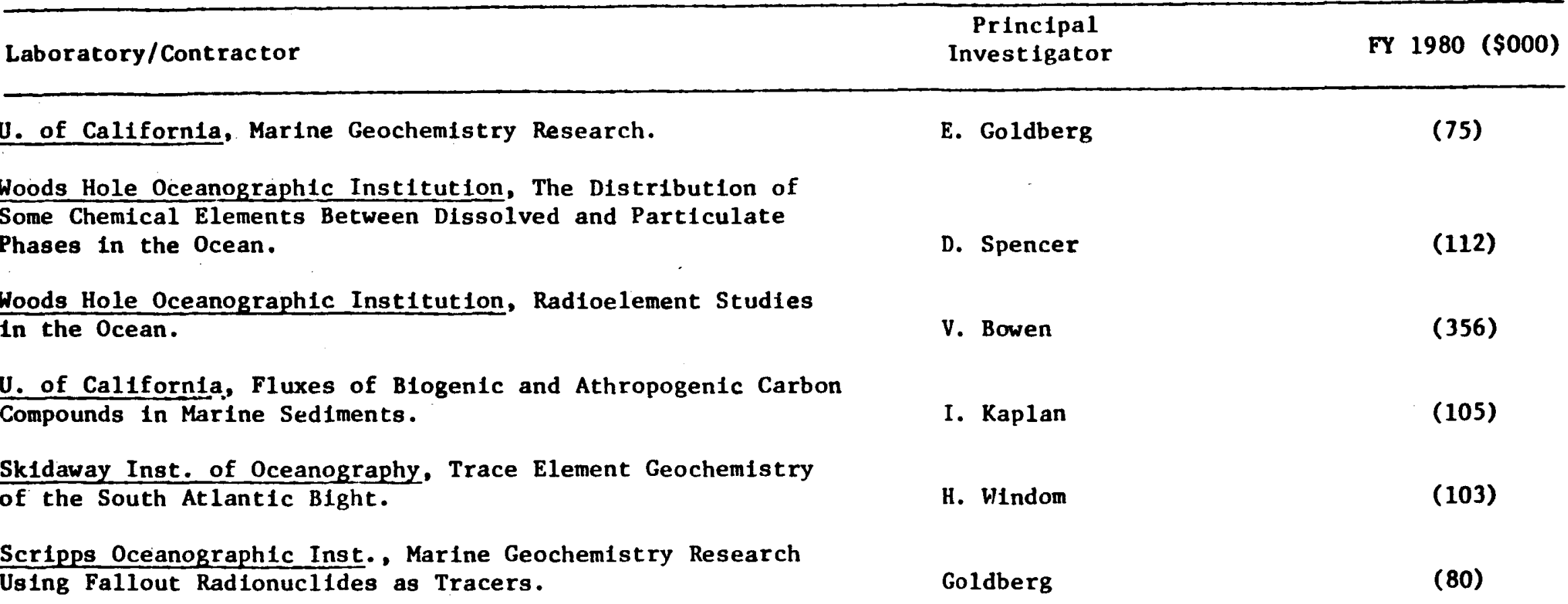

Est Imated Total 1950 
OFFICE OF HEAI,TH AND FNVIRONMENTAL RESEARCH

ECOLOGICAL RESEARCH DIVISION

GEOSCIENCES RIELATED RISEARCH

ECOSYSTEMS MODELLING

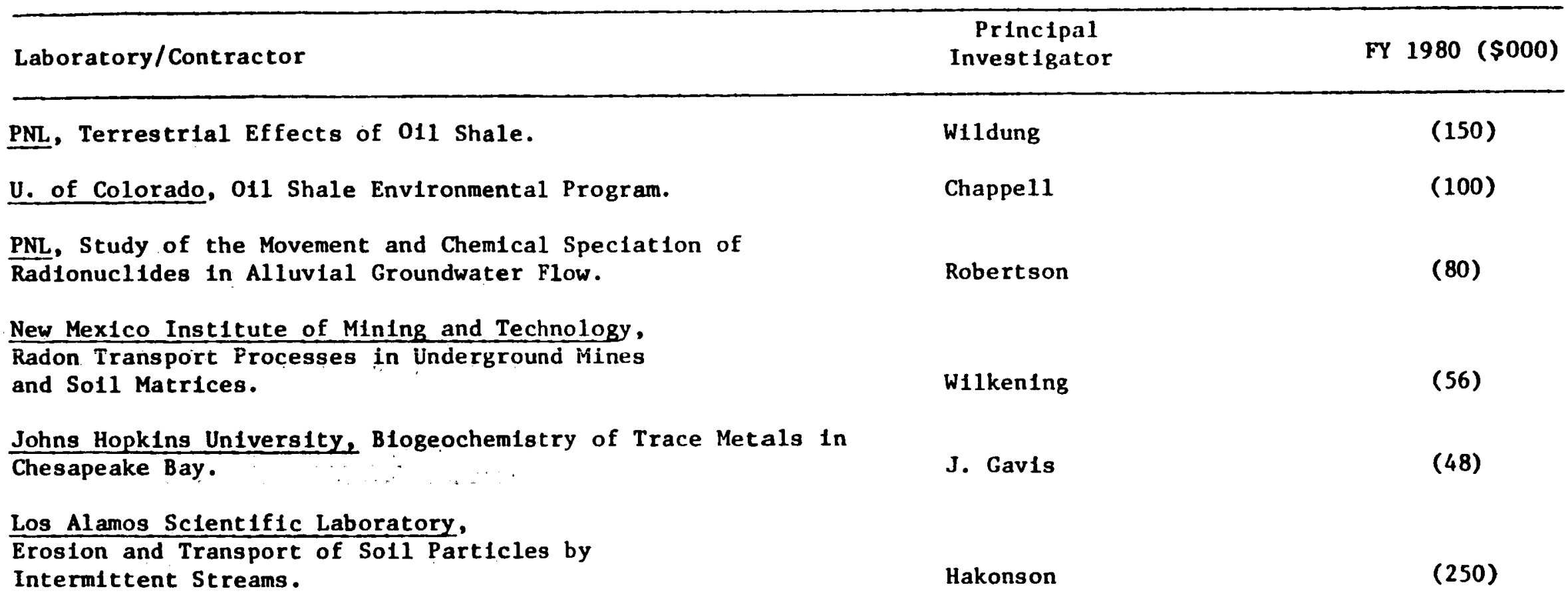


OFFICL OF HEALTII AND HNVIRONMINNTAI. RESEARCH

ECOLOG I CAL. RU:SLARCH IIVISION

GLOSCIENCLS RLLA'TIED RI:SEARCH

ECOLOGICAL EFFECTS OF LAND DISTURBANCES, INCLUDING RECLAMATION AND DISPOSAL OF WASTES FROM ENERGY SOURCES.

Laboratory/Contractor

University of Notre Dame,

Hydrological and Chemical Modeling.

PNL, Restoration of Surface Mined Land.

U. of Tennessee, Ecological and hydrological Aspects of Coal Mining.

Oak RIdge Natlonal Laboratory, Mob1lization and Transport of Leachates from Energy Solid

Wastes.

Principal

Investigator

FY $1980(\$ 000)$

Colorado State Unfversity, Rehabilitation Potential

of 011 Shale Lands.

Argonne Nat Ional Laboratory, Long Term Reclamation of 1 ands Mined for Coal, and hydrological effects.
The1s

Sauer

Minear

Cook

Carter

(1200) 
CE -1

Office of Energy Systems Research Division- of Energy Storage Technology Geosciences Related Projects (Operating Costs, Thousands)

Laboratory and Effort

Battelle PNL

Air/Water/Rock

Interactions with Compressed Air

Field Studies of Porous Rock Reservoirs

Aquifer Storage Program Environmental Assessment

Aquifer Thermal Storage Physiochemical Analysis

Aquifer Thermal Storage Numerical Simulations

Oak Ridge National Laboratory

Aquifer Storage Program Environmental Assessment

Lawrence Berkeley Laboratory

Aquifer Mathematical Studies
Principal Investigator (s)

$\underline{F Y 80}$

299

Rudd/Allen

548

Wukelic

95

Stat lemeyer

66

Kincaid

65

Lee

60

Twang

235 
Principal Investigator(s) $\quad$ FY80

Contract Research

Serata

71

Serata Geomechanics, Inc

Numerical Modeling of Salt

Caverns for Compressed Air

Louisiana State University

Laboratory Tests of Salt

Spec imens for Compressed Air

Thoms

160

RE/SPEC, Inc

Numerical Studies of Rock

Caverns for Compressed Air

Fossum

138

Auburn Univeristy

Field Studies of Aquifer

Molz/Parr/Melville

500

Thermal Storage

Century West Engineering

Regional Aquifer Assessment Study Stoffel

Oregon State University

Coupled Energy and Mass Transportation in Geologic Media

Childs 
Office of Renewable Technology

Division of Geothermal and Hydropower Technology

The purpose of the Department of Energy's geothermal program is to support the development and utilization of the Nation's geothermal resources as an economical, reliable, operationally safe, and environmentally acceptable energy source. This is accomplished through a comprehensive effort to develop new technologies that will promote more efficient and economical use of hydrothermal, geo-pressured, and hot dry rock resources. The program is carried out by the DOE national laboratories, Federal and State governmental agencies, universities, and private contractors. 


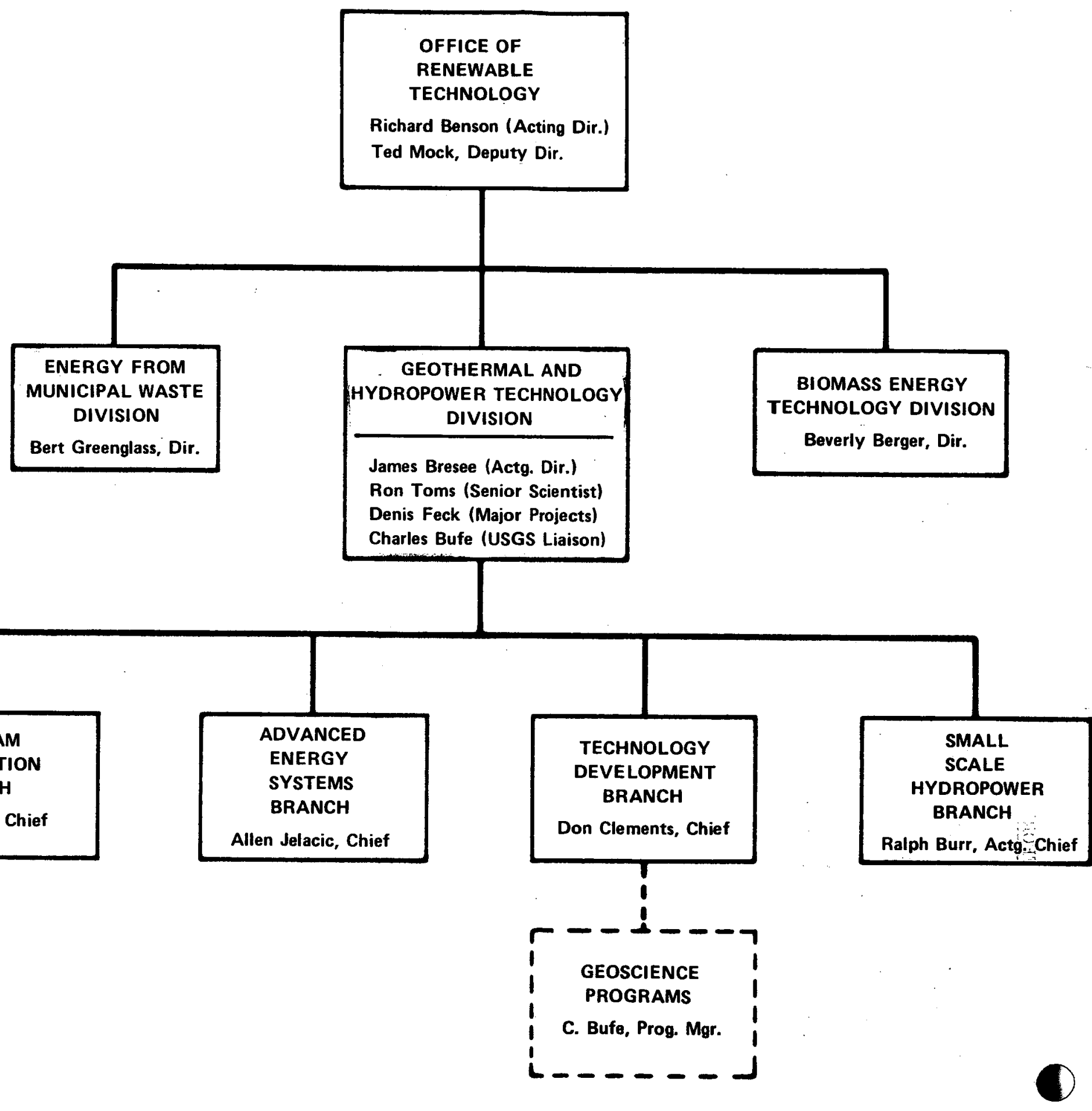


Division of Geothermal Energy

Geosciences Related Projects

(Operating Costs, Thousands)

LAWRENCE BERKELEY LABORATORY

Cerro Prieto Reservoir Case Study

Exploration Technology Development

Reservoir Engineering Management

Reservoir Engineering

Controlled Electromagnetic Surveys

Resistivity and Magnetic Surveys at Cerro Prieto

LAWRENCE LIVERMORE NATIONAL LABORATORY.

Tidal Pressure Response as a Reservoir Engineering Tool

LOS ALAMOS NATIONAL LABORATORY

Log Interpretation

Mathews

Laughlin

SANDIA NATIONAL LABORATORY

Geotherma1 We11 Logging Development

Lippmann $\quad 500$

Goldstein $\quad 424$

Howard $\quad 100$

Tsang $\quad 525$

Goldstein $\quad 100$

$\begin{array}{ll}\text { Goldstein } & 71\end{array}$

Hanson $\quad 140$

390

Arizona-New Mexico Low

Temperature Resource Assessment

Laughin

Veneruso

956 
Division of Geothermal Energy

\section{CONTRACT RESEARCH}

University of Alaska/State of Alaska, Department of Natural Resources: Geothermal Assessment in Alaska

Amax Exploration, Inc: Geothermal Reservoir Assessment

Amherst College: Survey of the Geothermal Potential of New England

Aminoil USA, Inc: Geothermal Reservoir Case Study

State of Arizona, Bureau of Geology and Mineral Technology: Low and Moderate Temperature Geothermal Evaluation

Barringer Research, Inc: The Application of Soil Geochemistry to Exploration for Concealed Geothermal Fields

State of California, Division of Mines and Geology: Geothermal Assessment and Reservoir Definition in California

University of California, Riverside: Application of Petrology and Geochemistry to the Study of Geothermal Reservoirs

Chevron Resources Co: Geothermal Reservoir Assessment Case Study

Colorado Geological Survey: Geothermal Assessment and Reservoir Definition in Colorado

Earth Sciences, Inc: Sulfur Gas Geochemical Detection of Hydrothermal Systems
PRINCIPAL INVESTIGATOR (s)

Turner/Schaff

200

0lsen

Brophy

65.4

Jenkins

Hahman

300

Meyers

94.4

Martin

Elders

181

Dahlstrom

150

Pear1

200

Rouse

70.5 
Electro Magnetic Applications, Inc:

A Study of the Characterization and Elimination of Cultural Noise in Active Source EM Surveys

Environmental Research Institute

Jackson

of Michigan: Simultaneous Analysis

of Multiple Data Sets

Fenix and Scisson:Geothermal

Drilling on Mt. Hood

Gruy Federal, Inc: Support for DOE's

Renner

Hydrothermal Resource Program

University of Hawail: Geothermal

Helsey

Assessment and Reservoir Definition

in Hawaii

Idaho Department of Water Resources:

Mitchell

Geothermal Assessment and Reservoir

Definition in Idaho

International Engineering Co: Geothermal

Zurflueh

75.5

Model Development Database contribution

Kansas Geological Survey: Geothermal Assessment and Reservoir Definition in Kansas

Lutech, Inc: Analysis of Three-Dimensiona1

Tesche Inverse Electrical Methods

Montana Bureau of Mines and Geology:

Sonderegger

Geothermal Assessment and Reservoir

Definition in Montana

National Oceanic and Atmospheric

Peeples

Administration: Geothermal Map

Theberge

284

Preparation

University of Nebraska: Geothermal.

Carlson/Gosnold

150

Assessment and Reservoir Definition

in Nebraska

Nevada Bureau of Mines and Geology:

- Trexler

200

Geothermal Assessment and Reservoir

Definition in Nevada

New Mexico Energy Institute:

Icerman

300

Geothermal Assessment and

Reservoir Definition in

New Mexico

University of New Mexico: Terrain

Jiracek

54.9

Effects in Resistivity and Mag-

netotelluric Surveys 
New York State Energy Research and Development Authority: State-Coupled Geothermal Energy Program

North Dakota Geological Survey: Geothermal Assessment and Reservoir Definition in North Dakota

Oregon Department of Geology and Mineral Industry: Geothermal Assessment and Reservoir Definition in Oregon and the Cascades

Princeton University: Development of a Geothermal Reservoir Simulator

University of Southern California: Borehole Measurements of In-Situ Velocity and Attentuation as Related to Rock Fracture Characteristics

Stanford University: Stanford Geothermal Program

System, Science \& Software, Inc1: Inversion Modeling of Multiple Geophysical Data Sets for Geophysical Exploration

University of Texas at Austin: Geothermal Resource Assessment for the State of Texas

Texas Energy and Natural Resources Advisory Council: Geothermal Exploration in Trans-Pecos, Texas/New Mexico

U.S. Geological Survey: Heat Flow Measurements

U.S. Geological Survey: Low Temperature Assessment

U.S. Geological Survey: Seismic Profiles in The Geysers-Clear Lake Area

U.S. Geological Survey: Computer Code Comparison
Krakow

376

Harris

100

Hu 11

526

Pinder

50

Henyey

87.9

Kruger/Ramey/Miller

300

Savino

89.5

Woodruff

Rao

170

Sass

Iyer

47.5

Sorey 
U.S. Geological Survey: Imperial Valley

Seismic Study

Utah Geological and Mineral Survey:

Gwynn

Geothermal Assessment and Reservoir Definition in Utah

University of Utah Research Institute:

Ross

Support of the Industry-Coupled Program

University of Utah Research Institute

Foley

Support of the State-Coupled Program

Vetter Research: Use of Tracers in

Vetter

Following Fluid Movement in

Hydrothermal Reservoir

Virginia Polytechnical Institute

Costain

1,597

and State University: Evaluation

and Targeting of Geothermal

Resources in the Southeastern

United States

Washington Department of Natural

Schuster

300

Resources: Geotherma1 Assessment

and Reservoir Definition in

Washington

University of Wyoming: Geothermal

Heasler

150 Assessment and Reservoir Definition in Wyoming 


\author{
Fossil Energy \\ Office of Oil, Gas and Shale \\ Oil Division \\ Advanced Process Technology Branch
}

\begin{abstract}
The goal of the Oil Division research and development program is to increase the production of oil from domestic sources by developing new and improved techniques of recovering oil from existing and potential oil reservoirs as well as non-conventional sources such as tar sand and oil shale. This program is designed to develop and evaluate advanced techniques to increase the rate of production; to recover more oil from existing reservoirs; and to develop the technology base relating to the production and use of petroleum and shale oil.
\end{abstract}

Currently, in the United States, there are 334 billion barrels of oil in place which are not recoverable through conventional recovery techniques. The research effort in the Enhanced Oil Recovery (EOR) program is designed to assist development of the technology to recover an increasing portion of this oil through new or improved methods.

The Nation's abundant western oil shale resource, equivalent to 1.8 trillion barrels, has the potential of contributing up to 600 billion barrels to our domestic oil supply using surface and in situ technologies that are currently in various stages of development. Additional shale oil may be recoverable from these shales and from the extensive but poorly-quantified eastern organic shales by potential technologies that are now in early stages of development.

The Advanced Process Technology activity supports the overall objectives of: (1) conducting advanced research in upgrading raw shale oil, heavy oil, and tar sands for transportation fuels, (2) producing and testing reference specification fuels to minimize required changes to engine design and costs, (3) investigating innovative technologies for recovering oil, gas, shale, and coal (in situ conversion) resources, (4) conducting fundamental materials and engineering research to overcome major barriers to advancing the state-of-the-art in drilling technologies in areas not pursued by industry, (5) conducting research in advanced drilling technology to include deep water and Arctic frontiers, and (6) providing engineering and advanced development support to the USGS and BLM in support of offshore and Arctic leasing and to the NSF for its oCS and deepsea drilling programs.

For the foreseeable future, the United States must rely upon fossil energy resources to supply the bulk of its energy. Drilling is an integral technology required for exploration and production of all petroleum, natural gas, $r$ coal, oil shale, and tar sand resources. Although the bulk of these domestic fuel resources are located onshore, the petroleum industry estimates that 60 to 70 percent of all additional petroleum discoveries will be made offshore on the Outer Continental Shelf (OCS). DOE estimates (1979) that in order to maintain current domestic levels of production at 10 million bbls/day, some 37 percent ( 20 percent oil 
and 17 percent gas) of all production in 1990 must come from the OCS. Estimates of potentially producible reserves in the U.S. OCS areas include 32 billion barrels of oil and 210 trillion cubic feet of natural gas.

Development of efficient, cost-effective drilling and offshore technology can have a pronounced effect upon the pace at which both conventional and unconventional fossil fuels are produced. In some cases (e.g., methane from coal, underground coal conversion and oil/gas" production from waters greater than 5,000 feet in depth), the development of new technology may determine whether a resource becomes a commercial reserve.

That part of the 0il Division's research and development related to geoscience research is focused in the Frontier Area Research branch (FAR).

The FAR research activities address the following program objectives:

- Improve the productivity of conventional drilling systems to increase average penetration rates and thus increase the total footage drilled per year by the U.S. drilling rig fleet.

- Develop advanced, more efficient ("revolutionary") drilling concepts for deep ocean and deep onshore applications.

- Develop required technology to drill and produce fossil fuels from both onshore and offshore "frontier" areas:

- very deep formations (greater than 30,000 feet)

- deep offshore waters (greater than 5,000 feet)

- Arctic environments

- Reduce or eliminate any adverse health, safety and environmental impact of both new and existing technology applications.

- Coordinate and/or provide direct research support to the Office of Oil, Gas and shale research development programs, to related programs within DOE (Geothermal, Energy Research and Environment) and to other Federal agencies (Departments of Interior, Defense, and Commerce).

Although the program research activities are affected by both technical and nontechnical (environmental, legal and socioeconomic) constraints, there are no known technological or physical barriers to development of improved drilling and offshore technology. Definition of specific goals and objectives coupled with the dedication of adequate funds, manpower and research facilities will produce specific improvements in drilling and offshore technology.

The program is separated into these subactivities:

$$
\text { itimin }
$$

- Advanced Drilling Technology

- Offshore and Arctic Technology 
The table below summarizes the funding levels by subactivity for the FY 1979 to FY 1981 period.

\begin{tabular}{|c|c|c|c|}
\hline $\begin{array}{c}\text { DRILLING AND OFFSHORE } \\
\text { TECHNOLOGY }\end{array}$ & \multicolumn{3}{|c|}{$\begin{array}{c}\text { BUDGET AUTHORITY } \\
\text { (DOLLARS IN THOUSANDS) }\end{array}$} \\
\hline SUBACTIVITIES & $\begin{array}{c}\text { ACTUAL } \\
\text { FY 1979 }\end{array}$ & $\begin{array}{c}\text { APPROPRIATION } \\
\text { FY 1980 }\end{array}$ & $\begin{array}{c}\text { ESTIMATE } \\
\text { FY 1981 }\end{array}$ \\
\hline ADVANCED DRILLING TECHNOLOGY & 1,510 & 1,500 & 1,120 \\
OFFSHORE \& ARCTIC TECHNOLOGY & 1,090 & 1,500 & 1,250 \\
TOTAL & 2,600 & 3,000 & 2,370 \\
\hline
\end{tabular}

A transitional organizational chart for the Assistant Secretary for Fossil Energy showing the structure and location of this program is in the following page.

\section{ADVANCED DRILLING TECHNOLOGY}

A true understanding of the need to increase the national drilling capability occurs only when the following information is studied. Essentially all the Nation's drilling rig fleet has been drilling at capacity since 1974, yet imports increased from 40 to 50 percent by 1979. It is clearly evident that additional capacity in annual drilled footage is absolutely essential if domestic production rates are to be significantly increased above the normal decline rates.

Some methods to increase the annual drilled footage capacity are listed below.

1. Increase activity in drilling research that will provide increased penetration rates, reduce non-rotating time, and provide basic research for drilling associated problems.

2. Increase or develop additional rig-building capacity.

3. Induce U.S. owned rigs which are drilling in foreign countries to be returned for domestic drilling.

A short description and status of each FE FY 1981 drilling initiative follows:

Bartlesville Energy Technology Center; Sandia Laboratories

High Performance Bit Technology: This research activity is directed toward optimizing rock removal techniques and bit hydraulics performance for newly developed polycrystalline diamond compact (PDC) drag bits. This work will investigate and quantify rock removal mechanisms, hydraulic behavior, heat transfer and other dynamic characteristics of drag bits used with high-speed downhole drilling motors. 
OFFICE OF THE ASSISTANT SECRETARY FOR FOSSIL ENERGY

(TRANSITIONAL ORGANIZATION)

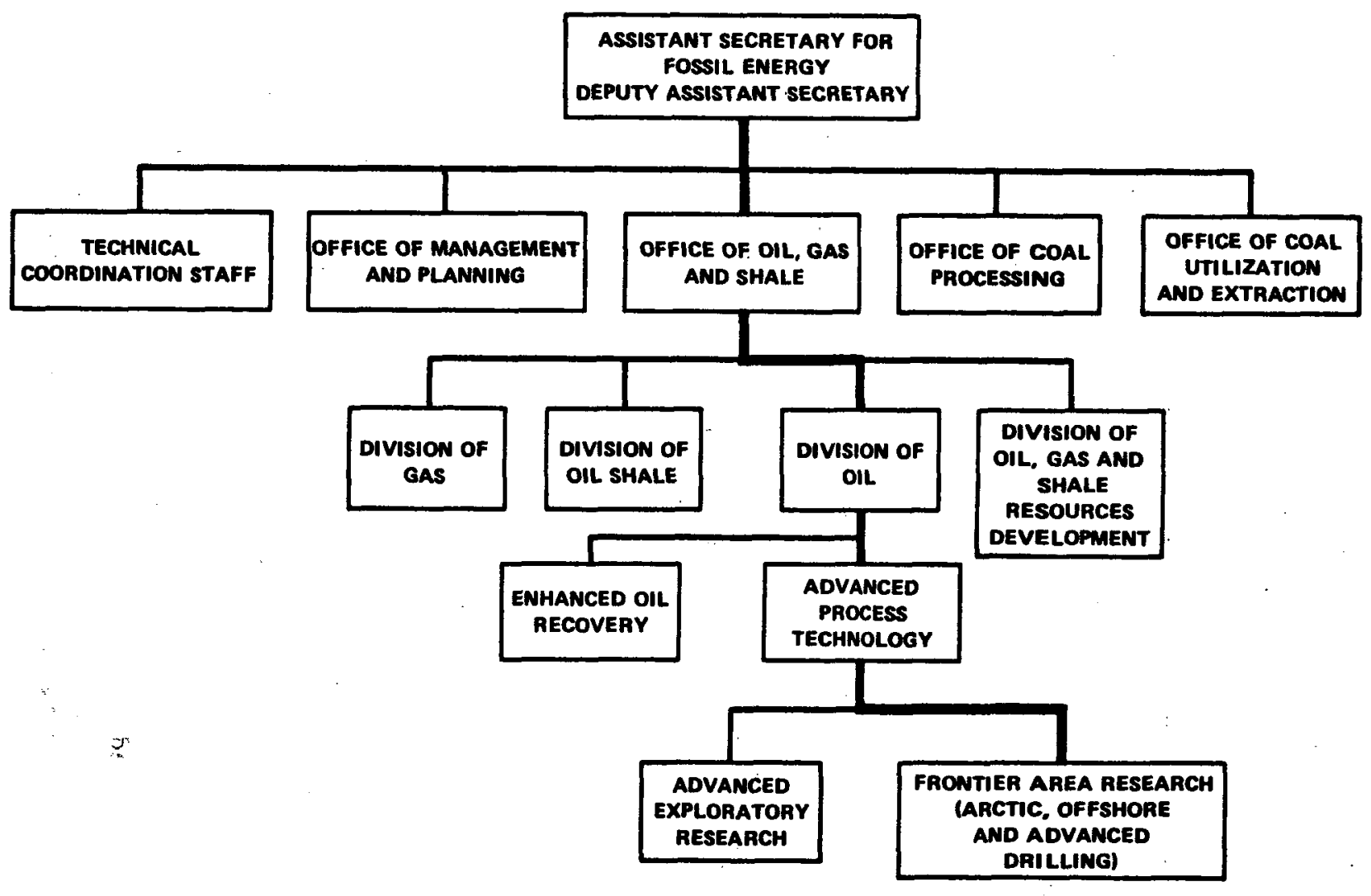


Fluid System Investigations: This activity will evaluate and quantify cuttings removal capabilities for various drilling fluids employed in very deep (greater than 20,000 feet) and highly deviated (30 degree - 90 degree angle) directionally drilled wells. Laboratory and field experiments will be augmented by computer modeling. Hole stability and particle transport phenomena in aerated fluids also will be experimentally investigated.

Materials Research: New high-temperature, high-pressure, and corrosion resistant alloys and elastomers will be tested to determine whether they are superior and more cost-effective materials for use in coatings, fillers, strengthening agents and fabrication of equipment components.

Instrumentation Development: This activity will provide for the development of downhole and surface sensors to be used in collection and processing of data required to optimize drilling operations.

Water Jet Drilling: Research will continue on the development of high-pressure hydraulic and cavitation jet cutting techniques for drilling small diameter (less than 18-inches) boreholes. A prototype water jet drilling system (see accompanying illustration) will be field tested to assess its application in drilling horizonal holes in coal seams for methane drainage.

Directional Drilling: Inertial guidance systems (an adaptation of a cruise missile guidance system) will be evaluated as a means of controlling downhole motors for precision directional drilling. A complete systems analysis, component testing (destructive and nondestructive) and field testing of the entire guidance assembly will be conducted.

Improved Pressure-Coring system: This system is being developed to provide industry with a reliable method for obtaining a pressurized core with reduced flushing at a reasonable cost. Obtaining an unflushed core will provide more accurate reservoir saturation data which is extremely important for reservoirs being considered for enhanced oil or gas recovery.

OFFSHORE AND ARCTIC TECHNOLOGY

\section{Offshore}

This proposed offshore research program can assist industry in providing near-term relief of domestic energy deficiencies. The program can influence the rate of development of offshore oil and gas resources.

It is evident that oil and natural gas will continue to b e the dominant components of the U.S. energy mix for the remainder of this century. Informed estimates indicate that from 50 to 60 percent of our total domestic energy supply will be provided by oil and gas in the year 1990 . offshore oil and gas production provides a significant portion of our currenty domestic production. Currently 13 percent of our domestic oil and 26 percent of our domestic gas are produced from the OCS. 
OCS oil and gas production will become even more important in the future. Industry estimates that the OCS will eventually provide 60 to 70 percent of all new petroleum discoveries. In addition, one-half of all domestic production must come from presently undiscovered resources by 1990 if oil production is to be maintained at 8.6 million barrels per day or increased.

Assessing such information regarding the U.S. energy situation, it is clearly evident that:

1. Oil and gas will remain the major energy source for the remainder of this century.

2. The OCS currently provides substantial amounts of oil and gas.

3. The OCS offers one of this Nation's best possibilities for new discoveries.

Therefore, there is a critical need to accelerate the development of this Nation's OCS petroleum resources to, as Secretary Edwards said during his confirmation hearings,". . emphasize capturing the enormous production potential of our own resources."

\section{$\operatorname{Arctic}$}

There is a great lack of basic knowledge regarding drilling and producing oil and gas wells in the Arctic environment. It is ecologically dangerous to operate in such a harsh, undefined environment without adequate research knowledge. However, oil operators recognize this and operate at the maximum state-of-the-art to achieve safety and efficiency. They build structures extra-strong to compensate for the lack of basic engineering data. The dangers persist, but the benefits and production potential are tremendous and the reserves must be developed. These reserves are the most favorahle source of useable "near-term" energy available to the United states.

Seventy percent of America's undiscovered recoverable offshore oil. resources are estimated in the $1980 \mathrm{U} . \mathrm{S}$. Geological Survey Circular 725 to 1 ie within the Continental Shelf of Alaska's coast. This consists of 19 billion barrels of oil and compares with a current annual production of about 2.2 billion barrels from the contiguous states and adjacent submerged 1 ands. Sixty percent of the Nation's undiscovered recoverable offshore gas resources also lie off Alaska's coast. These estimates are based on a 50 percent probability level.

The vast majority of Alaska offshore reserves 1 ie beneath the waters (and ice) of the Beaufort, Chukchi, and Bering Seas. These estimated reserves have become a principal focus in this Nation's effort to reduce its dependence on foreign petroleum supplies in favor of domesticnproduction. Commensurate with this goal, the Department of the Interior has scheduled seven initial oil and gas lease sales in the seifróntier areas during the period 1980 through 1985. Moreover, federal onshore petroleum development is scheduled to occur in the National Petroleum Reserve - Alaska (NPR-A). 
Although possessing a significant proportion of estimated U.S. petroleum reserves, these frontier areas present severe physical and climatological conditions and pose some of the most serious technological challenges ever experienced in the field of petroleum exploration and production. It is imperative that the technology employed in the Arctic reflect the most advanced state-of-the-art possible to ensure the safe and timely availability of petroleum products.

It was in recognition of this lack of knowledge and engineering data that the Federal Government scheduled its 1985 oil and gas leasing in the Chukchi Sea . . "contingent upon a reasonable assumption that technology will be available for exploration and development of the tracts included in the sale." Implementation of this proposed work can assist in obtaining the information needed to develop the technology.

Timely production of the Nation's domestic petroleum resources requires, therefore, that technological research in the Arctic be given high national priority. The achievement of this essential research will require the combined and complementary efforts of both the petroleum industry and those federal agencies whose missions relate to providing petroleum resources for the American public.

A short description and status of each of our FY 1981 offshore technology development initiatives follows:

- SEMS $(\$ 175 \mathrm{~K})$

The Seafloor Earthquake Measurement System (SEMS) is a device for measuring the motion of soil on the seafloor during earthquakes. Three SEMS units have been fabricated. They have been installed on the seafloor in the Santa Barbara (California) channel for a one year final test program. There has been intense industry interest in this program. No other devices of this kind are available. It will have important application in the Arctic, west coast, and other earthquake prone areas of the world.

- GISP ( $\$ 250 \mathrm{~K}$ DOE; $\$ 50 \mathrm{~K}$ USGS)

The Geotechnically Instrumented Seaflood Probe (GISP) is a pore pressure measurement device. Two prototypes have been fabricated. They were installed in the Gulf of Mexico for testing which was accomplished, after which some modifications were made at Sandia. The USGS has identified an area in the Gulf which has an extremely unstable (shifting) seafloor where the devices will be installed for further field tests. The data obtained will be used in the design andinitiation plans for offshore rigs. Ist:

- AcousticfTelemetry ( $\$ 220 \mathrm{~K})$ te.

This FY 1981 budget would be used to extend the range of a DOE previously developed acoustic telemetry system from its $600 \mathrm{ft}$. transmission range through water capability to a $4000^{\prime} \mathrm{range}$, and increase its data transmission rate. 
- Shear/Normal Force Gauge ( $\$ 220 \mathrm{~K})$

The shear/normal force gauge is a new concept for measuring soil strength in situ - applicable to deep water. The project will include developing and testing a prototype instrument. Ultimately it is planned that this system will measure both pore pressure and shear strength.

o Marine Sediment Penetrometer ( $\$ 150 \mathrm{~K})$

Hardware has been developed for measuring shear strength of seafloor soils, and numerous sediment penetration readings have been recorded. Work now underway includes modelling and performing detailed analysis of the data to determine shear measurement correlation data.

- Advanced Studies ( $\$ 135 \mathrm{~K})$

This program is designed to conduct advanced theoretical studies and identify key parameters related to research projects that should be done.

- Arctic Technology-Advanced Studies ( $\$ 68 \mathrm{~K}$ )

Due to estimated potential of up to 4 million barrels/day of oil production (vs 1.5 million barrels/day of current production) a program plan is being developed to define the research and development initiatives the DOE/FE must take to support rapid exploration and development of the Arctic Frontier.

UNIVERSITY CONTRACT RESEARCH AND DEVELOPMENT

Three university geoscience-related research projects are funded by this division:

- Stress Induced Fatigue Studies of Drill Pipe Immersed in Drilling Mud; University of Tulsa; 2 year

- Drill Cuttings Transport in Vertical Annuli by air, mist and/or foam; University of Tulsa; 2 year

- Analysis and Priorities for Arctic Offshore Technology Research; University of Alaska; 1 year 


\section{Division of $0 i 1$ Shale}

Part of the Oil Shale Program's technology base research at the Laramie Energy Technology Center includes mineralogic and Fischer Assay analysis of selected oil shale cores and drill cuttings to provide improved extrapolation of locations and quantities of oil shales that may be amenable to specific oil shale technologies that are being developed. Gross physical mineralogic description as well as $x$-ray mineral analysis is included. Samples are generally obtained from industrial drilling projects where available and are selected for their contribution to data gaps in the present knowledge of the resource. A core library is maintained for future reference needs. This effort is presently funded at $\$ 400 \mathrm{~K}$ in FY 1981. 


\section{Division of Gas}

The research projects sponsored by the Office of Gas that are related to Geosciences research are, as follows:

FY 1981

1. TRW, Inc.

$\$ 1,222,000$

A methane from coalbeds resource delineation effort covering the entire U.S.

2. Colorado Geological Survey

Evaluation of Colorado coalbed methane potential

3. Utah Geological and Mining Survey

Evaluation of Utah coalbed methane potential

4. Lawrence Livermore Laboratory

Fracture containment studies in relation to coalbed methane production from mineable coal seams

5. University of New Mexico

Resource assessment of coalbed methane from the

San Juan Basin

6. U.S. Geological Survey

Geologic characterization for western tight gas sands project

7. CER

Provides $10 g$ analyses and gas production geologic studies for western tight gas sands project

8. CER Corporation

Acquisition of core and logging data for western gas sands project

9. U.S. Geological Survey

Resource and reservoir characterization for western tight gas sands 
FY 1981

10. University of New Mexico

96,000

Development of core analysis techniques for $10 \mathrm{w}$ permeable gas reservoirs

11. Cliffs Minerals

775,000

Collection, description, and logging of EGSP Devonian shale cores

12. Terra Tek

600,000

Study of the interactions between fracturing fluid, proppants, and shale mineral components

13. U.S. Geological Survey

200,000

Geological, geochemical and geophysical appraisal of energy resources of the Devonian shale in the Appalachian Basin

14. Tetra Tech, Inc.

Assessment of shale production in dual completed wells

15. Mound Laboratories

$1,100,000$

Physical and chemical characterization of Devonian shale gas

16. Gruy Federa1

740,000

- Organization and collection of data from EGSP drilling, coring, and logging operations

- Gas well testing and analysis service in the Devonian shale

17. West Virginia University

- Characterization and evaluation of the Devonian shales in West "Virginia

- Analyses of structural geological parameters that influence gas production from the Devonian shale of the Appalachian Basin

- In situ stress determination based on fracture responses associated with coring operations 
FY 1981

18. Donohue, Onstey and Morrill

$1,170,000$

Testing of a new exploration technique using surface measurements of seismic velocity to locate zones of natural fractures in Devonian shales

19. Columbia Gas System Service Corporation

- Demonstrate the gas producing potential of the Devonian shale over a wide area in the Appalachian Basin

- Demonstrate state-of-the-art logging and stimulation techniques in relation to different geologic and stress conditions in the Appalachian Basin

20. Sandia National Laboratories $11,750,000$

Technical and management support for the western tight gas sands multiple well experiment 


\section{U.S. DEPARTMENT OF ENERGY}

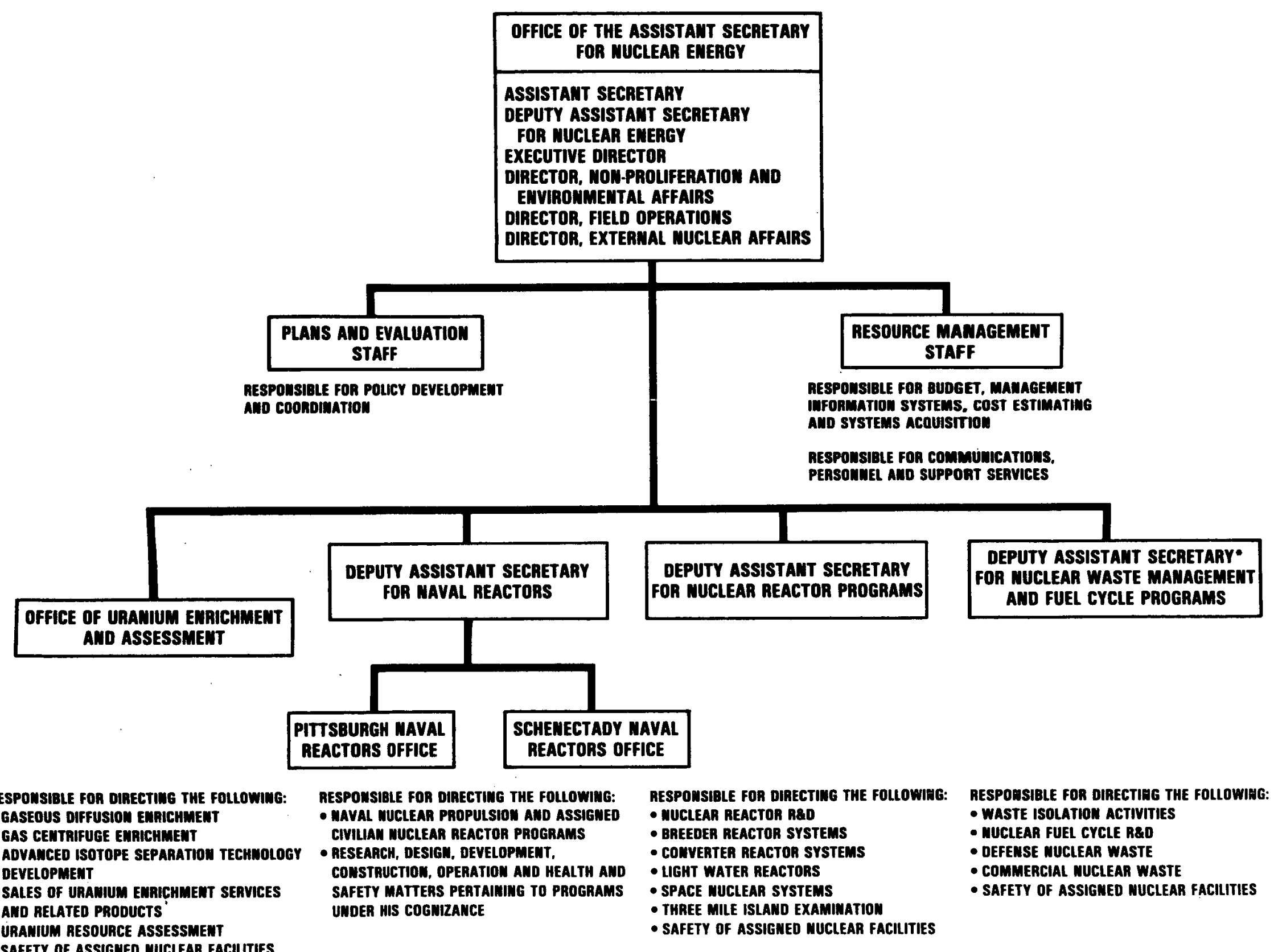

- SAFETY OF ASSIGNED MUCLEAR FACILITIES

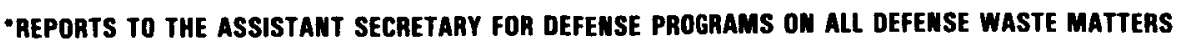


Title: Meteorological Studies

Performing Organization: NOAA, Air Resources Laboratory

Funding:

$\begin{array}{ccccc} & \underline{\text { FY 78 }} & \text { FY 79 } & \text { FY 80 } & \begin{array}{c}\text { Planned } \\ \text { FY 81 }\end{array} \\ \text { DOE } & \$ 250,000 & \$ 250,000 & \$ 240,000 & \$ 200,000 \\ \text { NRC } & \$ 220,000 & \$ 250,000 & \$ 225,000 & \$ 220,000\end{array}$

Summary:

This jointly-supported research project consists primarily of field measurements of meteorological dispersion to obtain dispersion parameters for a variety of. types of sites, particularly LMFBR program and potential reactor sites; field measurements of downwind tracer gas concentrations and related meteorological parameters over a wide range of distances, terrain, weather conditions and source configurations; development of validated dispersion parameters and improved calculational models; and performance of building wake effects studies. 
Title: Meteorological Effects of Thermal Energy Releases

Performing Organizations:

ORNL, PNL, ATDL (NOAA), Penn State, Rand, ANL

Funding: (NE share)

$\begin{array}{cccc}\text { FY 78 } & \text { FY 79 } & \text { FY 80 } & \begin{array}{c}\text { Planned } \\ \text { FY 81 }\end{array} \\ \$ 648,000 & \$ 450,000 & \$ 580,000 & \$ 400,000\end{array}$

Summary:

This jointly-funded (NE and EV) research project consists of the development of methods and a data base to assess the atmospheric effects of heat and moisture releases from large nuclear and fossil energy generating facilities. The atmospheric effects of interest include precipitation modification, fogging and icing, drift deposition and shadowing. Included in the program are effects from mechanical and natural draft cooling towers as well as cooling ponds. Primary emphasis is given to field studies with related analytical and physical modeling studies conducted as we11. Oak Ridge National Laboratory has been carrying out a precipitation study over a several year period at the 3160 MWe Bowen Power Plant in Georgia utilizing a dense raingage network around the plant to determine to what extent normal rainfall patterns are affected by thermal emissions from natural draft cooling towers. A report of six months of storm data was published in June 1979. Battelle Pacific Northwest Laboratories are assisting Oak Ridge in field testing and in data analysis. Other efforts include: (1) an analys is of drift deposition and transport from mechanical draft cooling towers; (2) airborne measurements of velocity, temperature, and huilidity in cooling tower plumes; (3) mathematical modeling to predict the occurrence of snowfall from natural draft cooling tower plumes; and (4) physical modeling of multiple plume interactions between adjacent cooling towers. 
The National Waste Terminal Storage (NWTS) Program was established in 1976 by the Department of Energy's (DOE) predecessor agency, the Energy Research and Development Administration. The purpose of the Program is to develop the technology and provide the facilities for the safe, environmentally acceptable, permanent disposal of high-level and transuranic nuclear wastes for which the Federal Government is responsible. Although alternative concepts are being investigated (e.g., subseabed disposal), principal emphasis is directed to waste disposal by emplacement in mined repositories in deep, stable geologic formations.

The NWTS Program will be carried out in four phases: Technology Development, Engineering Development, Operations, and Decommissioning. The first phase, Technology Development, is active and includes most of the geoscience-related research. The work of this phase is being accomplished by four separate, but coordinated, projects: 1) the Office of Nuclear Waste Isolation (ONWI), 2) the Basalt Waste I solation Project (BWIP), 3) the Nevada Nuclear Waste Storage Investigations (NNWSI) Project, and 4) the Subseabed Disposal Program. The first three projects are concerned with mined geologic disposal and are conducting work in the general areas of site evaluation and technology development, facility design, and field testing. In addition, ONWI, the lead contractor in the NWTS geologic repository development effort, has program coordination responsibilities and responsibilities for developing the criteria and technology that are generic to the design and safety assessment of mined geologic disposal systems.

With respect to evaluations of potential sites, BWIP is investigating basalt formations underlying DOE's Hanford Site in Washington State, NNWSI is investigating several different rock types underlying DOE's Nevada Test Site, and ONWI is evaluating geohydrologic systems within the contiguous United States. The ONWI siting investigations, which have historically focused on the potential of areas containing domed and bedded salt, have been expanded to include other rocks as well. The Subseabed Disposal Program is studying the technical and environmental feasibility of emplacing wastes in the sediments below the ocean floor.

Titles, objectives, and principal investigators for all NWTS geoscience research tasks are given in the following pages. The contract amounts are for the year FY 1980. The contract list covers a three year period, and hence the FY 80 amount may be different from those in FY 79 or FY 81 . An FY 80 amount of 0 means that the project was funded in one of these other years. 
LIST OF RESEARCH AND DEVELOPMENT CONTRACTORS PARTICIPATING

IN THE EARTH SCIENCES WORK OF THE NATIONAL WASTE

TERMINAL STORAGE PROGRAM

(AND ABBREVIATIONS)

Agapito and Associates

Argonaut Enterprises

Argonne National Laboratory (ANL)

Battelle Columbus Laboratories (BCL)

BDM Corporation (BDM)

Boyles Brothers Drilling Co.

BSC Richland, Inc.

Bechtel

Birdwell

Brookhaven National Laboratory (BNL)

Brown, R. E.

Colorado School of Mines (CSM)

Columbia University

Corps of Engineers

Dames and Moore

D'Appolonia

Esca-Tech

Exploration Data Consultants

Falcon Corporation

Fiber Materials, Inc. (FMI)

Fugro, Incorporated

Geochron

Georesults

Georgia Institute of Technology

Gonzales, S.

Hanford Engineering Development Laboratory

Hatch Drilling Co.

INTERA Environmental Consul tants (INTERA)

IRT Corporation (IRT)

$\mathrm{J}$. A. Jones Construction Company

Johnson, K. S.

Law Engineering and Testing Company (LETCO)

Los Alamos Scientific Laboratories (LASL)

Los Alamos Technical Associates (LATA)

Lawrence Berkeley Laboratories (LLL)

Lehigh University

Louisiana State University (LSU)

National Bureau of Standards (NBS)

Nevada Bureau of Mines

Nevada Operation's Engineering and Drilling Contractors (NVO Support Contractors)

New Mexico Institute of Mining and Technology (NMIMT)

New York University (NYU) 
Oak Ridge National Laboratory (ORNL)

Office of Nuclear Waste Isolation (ONWI)

Ohio State University (OSU)

Pacific Northwest Laboratories (PNL)

Pennsylvania State University (PSU)

Research Management Associates

$\mathrm{RE} / \mathrm{SPEC}$ Incorporated (RE/SPEC)

Rockwell Hanford Operations (RHO)

Sandia Laboratories, Albuquerque (SLA)

Savannah River Laboratories (SRL)

Science Applications Incorporated (SAI)

Seismograph Service Corporation

Shannon and Wilson

:i

South Dakota School of Mines (SDSM)

State of Idaho, Bureau of Mines and Geology

State of Oregon, Department of Geology and Mineral Industries

State of Washington, Department of Ecology and Department of

Natura1 Resources

Stone and Webster

Terra Tek

Texas A\&M University

Texas Bureau of Economic Geology (TBEG)

U.S. Geological Survey (USGS)

University of Arizona

University of California, Berkeley (UCB)

University of New Mexico (UNM)

University of Minnesota

University of Miami

University of Southern Mississippi (USM)

University of Texas, El Paso (UTEP)

University of Washington

Utah Geologic and Mineral Survey (UGMS)

Vitro Engineering Corporation

Washington State University

Waterways Experiment Station (WES)

Westinghouse Advanced Engineering Systems Division (Westinghouse AESD)

Westinghouse Electric Corporation (WEC)

Woodward-Clyde

Yale University 
A. IDENTIFICATION AND EVALUATION OF POTENTIAL

GEOLOGIC ENVIRONMENTS

FY 1980

$\left(\$ 000^{\prime} s\right)$

1. TITLE: National Screening of Geologic Environments $\$ \$ 500$

OBJECTIVE: To identify portions of the conterminous United States with potential for waste isolation, based on a comprehensive integrated literature search of geologic and environmental data.

PARTICIPANT: To be determined

2. TITLE: Geologic Evaluation of the Southeastern United States

OBJECTIVE: $\quad$ To evaluate the potential of geologic formations in the southeastern United States, especially the crystalline rocks of the Piedmont Province and argillaccous rocks of the Southeastern Coastal Plain, for the disposal of radioactive waste.

PARTICIPANT: $\quad$ SRL; I. Wende11 Marine

3. TITLE: $\quad$ Evaluation of West Texas Bedded Salt $\$ 2,500$

OBJECTIVE: $\quad$ To evaluate the regional geologic and hydrologic environments of the Palo Duro and Dalhart Basins of West Texas where extensive bedded salt occurs; to assist in selecting study areas for detailed characterization; and to inventory the natural resources of the basins.

PARTICIPANT: TBEG; C. R. Hanford

4. TITLE: Evaluation of the Salina Salt Basin $\quad \$ \quad 0$

OBJECTIVE: To evaluate the regional geologic and hydrologic environment of the Salina Salt Basin, New York and Ohio, where extensive bedded salt occurs; to select study areas for detailed characterization; and to inventory the natural resources of the Salina Basin.

PARTICIPANTS: J. H. Peck (Stone \& Webster),

S. E. Norris (USGS) 
2

5. TITLE: Geologic Evaluation of the Paradox Basin $\$ 9,600$

OBJECTIVE: To conduct, in sequence, regional, area, and site investigations for purposes of identifying, characterizing, and licensing a repository in bedded salt.

PARTICIPANTS: Donald MCMillan (UGMS), Robert Hite (USGS),

Fred Conwell (Woodward-Clyde)

6. TITLE: Survey of Crystalline Rocks $\$ \quad 0$

OBJECTIVE: $\quad$ To perform a reconnaissance survey of occurrences of crystalline rocks in the United States with potential for radioactive waste isolation.

PARTICIPANT: Dames and Moore; R. M. Winar

7. TITLE: Regional Evaluation of Crystalline Intrusive Rocks

OBJECTIVE: To undertake a detailed literature search and analysis of a region within the contiguous 48 states to evaluate the potential for future work in areas within the study region.

PARTICIPANT: To be determined

8. TITLE: Regional Geology of the Columbia Plateau

$\$ 1,281$

OBJECTIVE: To provide support for site selection and evaluation as wel1 as input for the Site Characterization Report, the Environmental Report, and the Draft Environmental Impact Statement. The knowledge obtained from this effort will be used to characterize the surrounding regional geology and the natural geologic events that have occurred or may occur in the future.

PARTICIPANTS: RHO; States of Oregon, Idaho, Washington; USGS; and others 
9. TITLE: Repository Support Geophysics for BWIP $\$ 1,667$

OBJECTIVE: To provide geophysical support to the development of a detailed structural and stratigraphic model of the proposed repository site. The support will include various types of geophysical surveys that will provide subsurface information at the repository site and surrounding areas.

PARTICIPANTS: RHO; Argonaut Enterprises; Seismograph Service Corporation

10. TITLE: $\quad$ Tectonic Studies of the Columbia Plateau $\$ 985$

OBJECTIVE: $13 \ldots$ To provide the data required for an assessment of the tectonic stability of the repository area. As part of this study, the capability of specific structures will be determined, per the NRC definitions, which could affect repository integrity.

PARTICIPANTS: RHO; Shannon and Wilson

11. TITLE: Develop Baseline Seismic Monitoring Plan for BWIP

OBJECTIVE: To develop a plan for preconstruction baseline monitoring of any possible microseismic activity in the vicinity of the repository. In addition, valuable data will be obtained for use in developing seismic design criteria.

PARTICIPANTS: RHO; Woodward-Clyde

12. TITLE: Operations of Initial Seismic Network at BWIP $\$ 489$

OBJECTIVE: To continue operation of the eastern Washington seismic network to provide continuing information on seismic events and travel times.

PARTICIPANTS: RHO; University of Washington 
13. TITLE: Regional Hydrology Studies of the Columbia Plateau

OBJECTIVE: To provide hydrologic data on the ground-water flow system of the basalts of the Columbia Plateau and how this flow system impacts the Pasco Sub-Basin flow system and to provide hydrological guidelines for selecting suitable candidate sites for a nuclear waste repository within the Pasco Sub-Basin portion of the Columbia River basalts.

PARTICIPANTS: RHO; State of Washington, Department of Ecology; Washington State University; PNL; R. E. Brown

14. TITLE: Integrated System Description of Basalt Hydrologic Regime, Preliminary Model Adaptations, and Modeling of Potential Credible Scenarios \$ 956

OBJECTIVE: To provide numerical analysis techniques for evaluation of radionuclide movement within the hydrologic system at the candidate site and within the Pasco Basin.

PARTICIPANTS: RHO; USGS; State of Washington, Department of Ecology; Georesults; BCS Richland, Inc.; Research Management Associates

15. TITLE: Characterization of Yucca Mountain Area, Nevada Test Site

OBJECTIVE: To assess the geologic, geophysical, and hydrologic characteristics of the Yucca Mountain portion of the southwestern NTS in sufficient detail to permit a judgement about the suitability of contained site(s).

PARTICIPANTS: G. L. Dixon (USGS); B. M. Crowe (LASL)

16. TITLE: Evaluation of Candidate Areas, Southern Nevada $\$ 150$

OBJECTIVE: To identify the most promising localities for waste isolation in southern Nevada, with special emphasis on the southwest quadrant of the Nevada Test Site (NTS).

PARTICIPANT: R. Byers (USGS); Nevada Bureau of Mines 
17. TITLE: Evaluation of the Hydrologic Flow System, Nevada Test Site (NTS) and Vicinity $\$ 750$

OBJECTIVE: $\quad$ To assess and digitally model in two dimensions the hydrologic flow system of the NTS and surrounding areas.

PARTICIPANT: D. I. Leap (USGS)

18. TITLE: Evaluation of Gulf Coast Salt Domes (Texas, Louisiana, Mississippi) $\$ 16,600$

OBJECTIVE: To evaluate the regional geologic and hydrologic environment of the Gulf Interior Region where numerous salt domes occur; to select study areas for detailed characterization; and to inventory the natural resources of the basin.

PARTICIPANTS: D. E. PaUTS (LETCO);

C. W. Kreitler (TBEG);

J. D. Martinez (LSU);

C. A. Spiers (USGS);

G. Ryals (USGS);

Oscar Paulson (USM)

19. TITLE: Characterization of Regional Ground-water system at WIPP

OBJECTIVE: To determine revised and refined potentio-metric and flow relationships between Capitan Reef and adjacent rocks for use in radionuclide migration and dissolution modeling.

PARTICIPANTS: D. D. Gonzales (SLA), hydrology

S. J. Lambert (SLA) geochemistry

20. TITLE: $\quad$ Repository Geology at BWIP $\quad \$ 382$

OBJECTIVE: To define, with as high a degree of certainty as possible, the geologic conditions which will be encountered in the repository.

PARTICIPANTS: RHO 
21. TITLE: Laboratory Evaluation of Argillaceous Rocks for Nuclear Waste Containment

OBJECTIVE: . To perform a fundamental investigation of physico-chemical properties of argillaceous rocks; and to identify and document their suitability as waste repository hosts.

PARTICIPANT: ORNL; G. Brunton

22. TITLE: Survey of Argillaceous Rocks

OBJECTIVE: $\quad$ To perform reconnaissance survey of occurrences of argillaceous rocks in the United States with potential for radioactive waste isolation.

PARTICIPANTS: K. S. Johnson; S. Gonzales

23. TITLE: High-Frequency Electromagnetic Borehole Techniques

OBJECTIVE: To determine capabilities and limitations of high frequency techniques for exploration of evaporites and crystalline rocks, to develop borehole equipment for radar and point-to-point transmission measurements, and to test this equipment at several sites to guide further development.

PARTICIPANT: USGS; Frank Frischknecht 
B. SITE CHARACTERIZATION

1. TITLE: Economic Geology Study at BWIP $\$ 239$

OBJECTIVE: To assess the potential for significant valuable resources that may be attractive to present or future generations.

PARTICIPANTS: RHO; ESCa-Tech

2. TITLE: Large-Hole Drilling and Boring Equipment

Capability Trade Study at BWIP $\quad \$ 0$

OBJECTIVE: To determine the capability of existing large-hole drilling and boring equipment for shaft and/or drift construction in support of repository development in the Columbia Plateau basalts.

PARTICIPANT: RHO

3. TITLE: Verification Studies of Specific Geologic

Structures of the Columbia Plateau $\$ 300$

OBJECTIVE: To provide geophysical support to the investigations carried out to determine capability of specific structures which could effect the repository.

PARTICIPANT: $\quad$ RHO

4. TITLE: Shale Structure Studies $\quad \$ 65$

OBJECTIVE: To determine the effect of elevated temperature on the chemical/physical structure of shales.

PARTICIPANT: Georgia Institute of Technology, Charles Weaver

5. TITLE: Seismic Effects of Weapons Tests at the Nevada Test Site \$ 275

OBJECTIVE: To statistically determine the surface and subsurface ground motion effects of underground nuclear explosions at potential repository areas on the Nevada Test Site.

PARTICIPANT: SLA; L. J. Vortman 
6. TITLE: Salt Permeability

OBJECTIVE: To assess the permeability of southeastern New Mexico rock salt for gas and liquid migration studies.

PARTICIPANT: SLA; J. R. Wayland

7. TITLE: Characterization of Local Ground-water System at WIPP

OBJECTIVE: $\quad$ To obtain description of hydrologic system for radionuclide migration modeling at WIPP.

PARTICIPANTS: D. D. Gonzales (SLA); J.W. Mercer (USGS)

8. TITLE: Evaporite Origins and Phase Relations in the WIPP Area

OBJECTIVE: To determine, empirically and theoretically, the conditions of stability and phase relations of evaporite minerals for evaluating the effects of physiochemical perturbations of heating experiments and hole plugging experiments.

PARTICIPANT: $\quad$ S. J. Lambert (SLA)

9. TITLE: Development of a Single Hole Electromagnetic Probe

OBJECTIVE: To develop and test an electromagnetic borehole probe that is capable of locating anomalies in the vicinity of a deep borehole (size, distance from the hole, and direction).

PARTICIPANT: R. J. Lytle (LLL) 
C. EARTH SCIENCE ASPECTS OF FACILITY DESIGN

AND OPERATIONAL RISK

1. TITLE: Near-Field Waste-Rock Interactions $\$ 211$

OBJECTIVE: To investigate the consolidation (compaction) behavior of crushed salt and to s.tudy brine.

PARTICIPANTS: PSU; Della M. Roy

2. TITLE: Salt-Brine-Waste-Canister Interactions $\$ 230$

OBJECTIVE: To determine the likely interactions among salt, brine, canisters, and waste at a range of temperatures and pressures that may be considered in disposal of high-level radioactive waste or spent fuel, and to determine the properties of the resultant reaction products at temperatures up to $300^{\circ} \mathrm{C}$.

PARTICIPANT: USGS; Rob Potter

3. TITLE: High-Leve1-Waste-Container Interactions with Rock Salt and Brine $\$ 693$

OBJECTIVE: To provide data and assess impacts of the interaction potentials of high-level waste forms and containers with the WIPP geologic, near-field environment.

PARTICIPANT: SLA; M. A. Molecke

4. TITLE: Brine Migration $\quad \$ 650$

OBJECTIVE: To determine the physiochemical properties of fluid inclusions in native rock and in artificially imposed heat fields. To evaluate the potential of fluid inclusions for waste-form degradation and radionuclide migration by performing laboratory, bench-scale, and in situ experiments for assessment of brine migration phenomena.

PARTICIPANTS: H. C. Shefelbine (SLA)

S. J. Lambert (SLA)

A. R. Sattler (SLA)

E. Roedder (USGS) 
5. TITLE: Effect of Water on Salt Repository

OBJECTIVE: To gain information sufficient to predict credibly the consequences of any plausible form of water breeching a salt repository that might compromise the integrity of that repository.

PARTICIPANT: ORNL; Charles Baes

6. TITLE:

Radiolysis of Brine

OBJECTIVE: To provide experimental information on the effects on brines under conditions appropriate to the very nearfield environment of a repository in salt.

PARTICIPANT: ORNL; Glen Jenks

7. TITLE:

Expected Repository Environments $\$ 300$

OBJECTIVE: To identify reference conditions in salt, shale, and granite repositories to serve as a guide for:

(a) scientists conducting material performance tests,

(b) engineers preparing the design of repositories,

(c) the technically conservative conditions to be used

as a basis for DOE application for a license, and

(d) scientists and engineers developing waste forms.

PARTICIPANTS: RHO (BASALT); H. C. Claiborne (ORNL)

L. D. Rickertsen (SAI)

G. D. Callahan (RE/SPEC)

8. TITLE: Transient Creep in Rock Salt $\$ 62$

OBJECTIVE: To develop and test a transient creep constitutive relationship for salt.

PARTICIPANT: Texas A\&M University; David Parrish

9. TITLE: Bench Scale Creep Tests on Rock Salt $\$ 35$

OBJECTIVE: To perform creep tests on large natural blocks of salt. PARTICIPANTS: SDSM; William Grams, Charles Gessner 
10. TITLE: Thermomechanical and Brine Migration In Situ

Tests in Dome Salt at Avery Island $\$ 400$

OBJECTIVE: To provide field engineering support to in situ tests at the Avery Island Mine examining thermomechanical effects and brine migration in dome salt.

PARTICIPANT: Wayne Krause (RE/SPE)

11. TITLE: U.S./Federal Republic of Germany (FRG) Cooperative Efforts in Asse

OBJECTIVE: To develop and perform field tests, initially involving brine and gas migration and waste/rock interaction, at the Asse Salt Mine, FRG, which has capabilities currently unavailable in the U.S.

PARTICIPANT: Westinghouse AESD; Don Newby

12. TITLE: Operation and Design Support Tests for WIPP $\$ 507$

OBJECTIVE: To provide in situ evaluation of facility design parameters and operational procedures as inputs to the WIPP engineering design and operational safety procedures.

PARTICIPANT: WEC; Bechte1, A. R. Sattler (SLA)

13. TITLE: Thermomechanical Testing in Stripa Granite $\$ 1,565$

OBJECTIVE: To provide data on the effects on the integrity of granite in a deep geologic formation that is subjected to long-term high heat loads.

PARTICIPANT: LBL; Paul Witherspoon

14. TITLE: Material Properties of Stripa Granite $\$ 130$

OBJECTIVE: To measure the material properties of carefully selected rock samples from the granite rock mass at the Stripa mine that are needed to understand the hydraulic, thermal, and rock mechanic behavior of the fracture rock mass.

PARTICIPANTS: LBL; Paul Witherspoon 
15. TITLE: Directional Permeability of Stripa Granite $\$ 259$

OBJECTIVE: To define the surface and subsurface hydrological conditions of the fractured granite rock mass as a function of time and temperature.

PARTICIPANT: LBL; Paul Witherspoon

16. TITLE: Macroscopic Permeability of Stripa Granite. $\$ 100$

OBJECTIVE: To determine the gross seepage rate in a mined drift at Stripa and to correlate this rate with hydraulic pressure to determine the global permeability of the fractured rock mass.

PARTICIPANT: LBL; Paul Witherspoon

17. TITLE: U.S./Swedish Cooperative Efforts at Stripa, Sweden $\$ 0$

OBJECTIVE: To carry out tests dealing primarily with buffer material and sealing, and hydrogeological aspects in fractured granite at depth in the Stripa mine.

PARTICIPANT: ONWI; R. A. RObinson

18. TITLE: Evaluation of Geophysical Techniques in Fractured Crystalline Rock

OBJECTIVE: To determine the applicability of different surface, subsurface, and borehole geophysical techniques in delineating and characterizing the fracture systems, in the granite body at Stripa.

PARTICIPANT: LBL; Paul Witherspoon

19. TITLE: Near-Surface Test Facility Design, Construction, and Operation $\$ 16,716$

OBJECTIVE: The design and construction of a multipurpose Near-Surface Test Facility for the in situ testing of basalt.

PARTICIPANTS: RHO; J. A. Jones Construction Company; Vitro Engineering Corporation 
20. TITLE: In Situ Stress Measurement Techniques

OBJECTIVE: To determine the in situ state of stress in the fractured granite rock mass in the Stripa mine.

PARTICIPANT: JLBL; Paul Witherspoon

21. TITLE: Support of Geotechnical Test Facility at the Colorado School of Mines (CSM)

Experimental Mine

OBJECTIVE: To provide an experimental facility in crystalline rock to conduct in situ tests, and to develop hard rock mining methods to aid in crystalline rock repository development.

PARTICIPANT: CSM; William Hustrulid

22. TITLE:

Heated Block Flatjack Test

$\$ 250$

OBJECTIVE: To provide an in situ data base of thermomechanical rock properties for development and evaluation of mathematical models, and to provide a test for the in situ calibration of rock instrumentation.

PARTICIPANTS: Terra Tek; Howard Pratt

23. TITLE: Climax Spent Fuel Test $\$ 5,000$

OBJECTIVE: To evaluate the feasibility of safe and reliable emplacement, short-term storage, and retrieval of spent reactor fuel assemblies and plausible repository depth in a typical granite rock; to obtain technical data about the suitability of granite as a medium for deep geological disposal of high-level reactor waste; and to obtain information about the design of a repository in granite.

PARTICIPANT: NVO Support Contractors; L. D. Ramspott (LLL)

24. TITLE: Granite Heater and Rock Mechanics Tests, Climax Stock

$\$ \quad 0$

OBJECTIVE: To analyze and document the results of granite heater test No. 1; and plan subsequent in situ granitic thermal and rock mechanic experiments.

PARTICIPANT: LLL; L. D. Ramspott 
25. TITLE: Nuclide Migration Studies in Fractured Granite:

CT imax, NTS

$\$ 250$

OBJECTIVE: (1) To study radionuclide migration in fractured granite;

(2) to compare in situ retardation factors with laboratory values; and (3) to model fracture flow in granite and calibrate the model using in situ values.

PARTICIPANT: LLL; David Coles

26. TITLE: Waste/Barrier/Rock Interractions in Basalt

$\$ 1,492$

OBJECTIVE: To determine the hydrothermal interactions which will occur following a worst circumstance breach of the engineered barrier system.

PARTICIPANTS: RHO; PSU; PNL

27. TITLE: Characterization of Waste Form and Geologic

Environment for BWIP

$\$ 1,020$

OBJECTIVE: To obtain physical, chemical, and structural data from analyses of candidate waste forms, natural ground waters, and potential geologic barriers.

PARTICIPANTS: RHO; LBL; Hanford Engineering Development Laboratory; PNL

28. TITLE: $\quad$ Advanced Rock Testing of Basalt $\$ 464$

OBJECTIVE: To determine rock properties for basalt at the Near-Surface Test Facility and for deep basalt flows under the Hanford Site.

PARTICIPANTS: RHO; CSM

29. TITLE: Heater Test Data Analysis and Repository

Design for BWIP

$\$ 645$

OBJECTIVE: To assess the suitability of basalt as a repository medium from a thermomechanical viewpoint and to develop the computer modeling capability needed to procede with design, construction, and licensing of a basalt repository.

PARTICIPANTS: RHO; University of Maryland 
30. TITLE: Borehole Plugging in Basalt $\$ 2,014$

OBJECTIVE: To develop and demonstrate the technology needed to effectively seal all man-made openings to a nuclear waste repository within the basalts of the Columbia Plateau.

PARTICIPANTS: RHO; Woodward-Clyde

31. TITLE: Ground-water Monitoring System Criteria for Basalt

OBJECTIVE: To prepare criteria and requirements (if any) for monitoring - ground-water movement in the immediate vicinity of the repository.

PARTICIPANT: RHO

32. TITLE: Argililite Study $\$ 90$

OBJECTIVE: To characterize the near-field response of argillite to simulated thermal, mechanical, and chemical conditions created by emplacement of high-level radioactive wastes.

PARTICIPANTS: L. D. Tyler (SLA)

$K$. Wolfsberg (LASL)

33. TITLE: In Situ Test--Conasauga Shale $\$ Q$

OBJECTIVE: To measure the thermomechanical response and mineralogical changes that occur near a heat source in the Conasauga shate.

PARTICIPANT: SLA; L. D. Tyler

34. TITLE: Nuclide Migration Studies in Tuff:

G-Tunne 1, NTS $\$ 250$

OBJECTIVE: To develop the techniques for and to conduct controlled field experiments to define radionuclide migration through tuffs.

PARTICIPANT: Keith Johnstone (LASL) 
35. TITLE: Tuff Study $\$ 2,500$

OBJECTIVE: To develop and apply means to characterize the near-field response of selected tuff units to simulated thermal, mechanical, chemical, and fluid conditions created by emplacement of high-level radioactive waste.

PARTICIPANTS: L. D. Tyler (SLA)

K. Wolfsberg (LASL)

36. TITLE: Engineered Barrier Optimization $\$ 408$

OBJECTIVE: To assess the capabilities of individual engineered barriers, evaluate the mutual compatibility of various components of the waste package, and specify acceptable barrier assemblages.

PARTICIPANTS: RHO; PNL

37. TITLE: Waste Rock-Interaction Technology: Leaching $\$ 1,800$

OBJECTIVE: To determine waste form release rates and help provide source terms for consequence analysis. More specifically: to characterize candidate waste forms; to measure leach rates with solutions and under conditions simulating expected repository conditions; and to determine the effects of physical and chemical factors on release mechanisms.

PARTICIPANT: PNL; Donald Bradley

38. TITLE: Transuranic Waste Characterization Studies Under Conditions of Geologic Isolation $\$ 333$

OBJECTIVE: To obtain data and predictive analytical models on the interaction and degradation behavior of existing and development TRU wastes in a bedded salt repository environment.

PARTICIPANTS: LASL; SRL; UNM; M. A. Molecke (SLA)

39. TITLE: Analysis of Thermomechanical Response of Rock $\$ 178$

OBJECTIVE: To develop the capability for detailed simulation of demonstration tests as well as laboratory tests and the capability necessary for simulation of repository behavior.

PARTICIPANT: SAI; Ronald Hofmann 
40. TITLE: Modeling of Thermal-Structural Interactions

in Salt

$\$ 562$

OBJECTIVE: To provide the analytical modeling for prediction of near-field and far-field response of salt and associated overlying media.

PARTICIPANT: SLA; J. R. Wayland

41. TITLE: $\quad$ Salt Model Pillar Studies $\quad \$ 100$

OBJECTIVE: To understand long-term creep behavior of salt as a function of temperature, stress, and time.

PARTICIPANT: ORNL; Tom Lomenick

42. TITLE: Spent Fuel Canister and Room/Pillar Convective Heat Transfer $\$ 157$

OBJECTIVE: To investigate experimentally and analytically the convective heat transfer aspects related to near-field thermal performance.

PARTICIPANTS: OSU; F. A. Kulacki, R. N. Christensen

43. TITLE: Independent Measurement Laboratory and Rock Properties Handbook

$\$ 600$

OBJECTIVE: To develop and operate an independent measurement laboratory as a part of the Energy Technology organization for materials characterization, and to determine the feasibility of authoritative documentation of the physical property data of basalts, granites, and shales and to perform pilot evaluations of typical data.

PARTICIPANTS: NBS; H. Thomas Yoklen (Independent Measurement Laboratory) L. H. Gevantman (Rock Properties Handbook)

44. TITLE: Fracture Permeability of Rocks Under Pressure $\$ 270$

OBJECTIVE: To measure the fracture permeability in rock (core samples) as a function of pressure and relate it to the acoustic and electrical properties of the rocks.

PARTICIPANT: LLL; H. C. Heard 
45. TITLE: Permeability Studies

$\$ 95$

OBJECTIVE: To determine very low permeability characteristics in the laboratory of several potential repository host rocks under various conditions of temperature and confining pressure.

PARTICIPANT: LLL; H. C. Heard

46. TITLE:

Determination of Elastic Constants

$\$ 45$

OBJECTIVE: $\quad$ To determine the effects of pressure and/or temperature on the rock elastic constants.

PARTICIPANT: 'LLL; H. C. Heard

47. TITLE: Mechanical Behavior of Rocks Under Pressure $\$ 190$

OBJECTIVE: To test rock samples to determine thermal conductivity, thermal diffusivity, heat capacity, and linear thermal expansion coefficient as a function of combined pressure, temperature, and pore water pressure, and to gain an understanding of the interrelationship between thermal properties and sample composition, fabric, and degree of fracturing.

PARTICIPANT: LLL; ATbert Abey

48. TITLE: Experimental Study of Opening Mode Crack Growth in Rock

OBJECTIVE: To study crack growth mechanisms in rock.

PARTICIPANT: Yale University; R. B. Gordon

49. TITLE: Laboratory Measurements--Mechanical

Properties

$\$ 50$

OBJECTIVE: To perform materials properties tests on rock specimens.

PARTICIPANT: Terra Tek 
50. TITLE: Thermal Properties Measurements

OBJECTIVE: To provide measurements of thermal properties of a large number of samples on a routine basis as various sites are explored and geologic and other data obtained.

PARTICIPANTS: M. T. Morgan (ORNL)

J. F. Lagedrost. (FMI)

51. TITLE: Thermal-Structural Interaction in Salt-Laboratory Experiments

OBJECTIVE: To provide thermophysical properties of WIPP rock salt and surrounding media and to obtain data on elastic and creep behavior to support development of appropriate constitutive models.

PARTICIPANTS: SLA; J. R. Wayland, W. Wawerski

52. TITLE:

Tectonic Stability--ERDA 6 Test Borehole

$\$ \quad 0$

OBJECTIVE: To conduct adequate tests of reservoir size (1 arge brine pocket) and adjustment during testing and to obtain additional samples of brine for study of genesis of structure and fiuid.

PARTICIPANTS: SLA; D. W. Powers, S. J. Lambert, R. D. Statler

53. TITLE:

OBJECTIVE:

PARTICIPANT: LBL; PaUT Witherspoon
Feasibility of an In Situ Test Facility

To perform a feasibility study on the possibility of developing an underground test facility (UTF) in hard rock.

54. TITLE:

U1tra-Large Rock Core Tests

$\$ 240$

OBJECTIVE: To perform laboratory testing to: (1) investigate effects of scale, state of stress, fluid pressure, and temperature on measured properties of rocks and rock fissures; (2) conduct site-specific core testing (i.e., Stripa, BWIP, NTS); and (3) investigate the relationship between fissure permeability and dilatency due to shear loading.

PARTICIPANT: LBL; PauT Witherspoon 
55. TITLE:

OBJECTIVE: for in situ experiments (short-term) and repository monitoring functional requirements (long-term).

PARTICIPANT: To be determined.

56. TITLE:

Application of Acoustic Methods

OBJECTIVE: To determine whether acoustic methods can be used in the near-field environment to monitor fracture development and/or slip along fractures during the thermal pulse.

PARTICIPANT: LBL; Thomas MCEvilly

57. TITLE:

OBJECTIVE:
Data-Transmission Alternatives

To conceptually develop and analyze techniques to transmit data from subsurface instrumentation in or at the repository to the biosphere without breaching repository geologic integrity. These concepts will apply generically to all candidate repository media.

PARTICIPANT: To be determined.

\section{TITLE: Borehole Instrumentation} $\$ \quad 99$

OBJECTIVE: To develop an underground telemetry system capable of measuring an in situ physical property and transmitting the data to the surface.

PARTICIPANT: IRT; Rod Galloway

59. TITLE: Instrumentation Development for In Situ Testing

OBJECTIVE: To develop thermomechanical and thermochemical instrumentation for application to pre-WIPP in situ experiments, for measurements for which commercially available instrumentation is inadequate or not available.

PARTICIPANT: SLA; A. R. Sattler 
60. TITLE: Instrumentation Needs for In Situ Experiments $\$ 37$

OBJECTIVE: To determine instrumentation requirements for all current and planned NWTS in situ tests and define corresponding developmental needs.

PARTICIPANT: OSU; DOn Miller

61. TITLE: State-of-the-Art Review of Measurement

Techniques for Nuclear Waste Disposal $\$ 50$

OBJECTIVE: To assess the value of various types of instrumentation which will be used during the site evaluation phase, the site construction phase, and the long-term monitoring phase.

PARTICIPANT: Terra Tek; Howard Pratt

62. TITLE: Short-Term Hydraulic Effects $\$ \quad 0$

OBJECTIVE: To simulate with a digital model the fluid-pressure response measured near an electrical heater source in the granite of the Climax Stock.

PARTICIPANT: USGS; D. D. Gonzales

63. TITLE: Thermal Structural Interaction--Bench Scale and In Situ $\$ 206$

OBJECTIVE: To conduct bench-scale and in situ tests which serve to assess and demonstrate the validity of predictive models.

PARTICIPANTS: SLA; J. R. Wayland, A. R. Sattler

64. TITLE: Release Rates of Reactor Products $\$ 175$

OBJECTIVE: To identify and quantify the release of radionuclides from irradiated $\mathrm{UO}_{2}$ fuel elements and synthetic and natural uraninite minerals under conditions of geologic disposal.

PARTICIPANT: LASL; Edward Norris 
65. TITLE: Thermodynamic Properties of Actinides $\quad \$ \quad 250$

OBJECTIVE: To provide thermodynamic data on the species, oxidation states, and concentrations of radionuclides in solution under geologic repository conditions.

PARTICIPANT: LBL; Norman Edelstein

66. TITLE: $\quad$ Strain Related Radiation Damage $\quad \$ 190$

OBJECTIVE: To determine the combined effects of strain and irradiation over a range of temperatures in candidate host rock materials.

PARTICIPANT: BNL; PaUT Levy

67. TITLE: $\quad$ Repository Concepts Analysis $\quad \$ 490$

OBJECTIVE: To provide laboratory testing capability for characterizing salt and other rocks in a repository environment and numerical support on generic conceptual repository design.

PARTICIPANTS: G. D. Callahan; P. F. Gnirk, RE/SPEC

68. TITLE: Development of Displacement-Discontinuity

Models

$\$ 125$

OBJECTIVE: To develop displacement-discontinuity models for analysis of conceptual repository designs.

PARTICIPANTS: University of Minnesota; Steve Crouch, Christopher St. John

69. TITLE: Borehole Plugging--Cement and Geochemical

Studies

$\$ 600$

OBJECTIVE: To develop a better basic understanding of the parameters that relate to placement and long-term stability of cementitious composites, to evaluate the geochemistry of cementbased materials, and to help determine the longevity and durability of cementitious composites in the repository environment.

PARTICIPANTS: Katherine Mather (WES)

Della M. Roy (PSU) 
70. TITLE: Geotechnical Design Studies for Repository Sealing

OBJECTIVE: To establish repository sealing design criteria that will become the basis for determining the needs of all related laboratory, field testing, analytical, and licensing efforts in the NWTS program.

PARTICIPANT: D'Appolonia; Dick Ellison

71. TITLE: Borehole Plugging--Cement Technology Studies $\$ 0$

OBJECTIVE: To investigate methods for improving the precision of physical testing of cementitious solids.

PARTICIPANT: ORNL; John Moore

72. TITLE: Borehole Plugging Field Tests $\$ 1,600$

OBJECTIVE: To demonstrate borehole plugging technology using the best available current methods, materials, and instrumentation.

PARTICIPANTS: SLA; C. L. Christensen 
D. EARTH SCIENCE ASPECTS

OF LONG-TERM RISK ANALYSIS

1. TITLE: Effect of Surficial Processes on the Columbia Plateau $\quad \$ 96$

OBJECTIVE: To analyze those surficial processes with potential for affecting a repository. As part of this activity, quantitative measurements of denudation rates will be determined and coupled with maximum possible rates of uplift to examine any possible effect on a repository.

PARTICIPANTS: RHO; Woodward-Clyde

2. TITLE: Evaluation of Dissolution of Evaporities near WIPP Area

OBJECTIVE: To determine amount, extent, and nature of dissolution of evaporites due to effects of superjacent water-bearing rocks.

PARTICIPANTS: G. 0. Bachman (USGS); S. J. Lambert (SLA); J. W. Mercer (USGS); D. G. Brookins (UNM)

3. TITLE: Subsidence Over Mines in Evaporites

OBJECTIVE: To determine effects of evaporite removal on overburden subsidence and disruption of overlying water-bearing units, for implications regarding mine-induced dissolution.

PARTICIPANTS: J. W. Mercer (USGS); D. W. Powers (SLA)

4. TITLE: Characterization of Consolidated Rubble Chimney

$\$ 750$

OBJECTIVE: To determine nature and origin of consolidated rubble chimney (breccia pipe) and to evaluate magnitude of threat of such features for contributing toward dissolution of evaporites.

PARTICIPANTS: C. L. Jones (USGS); J. W. Mercer (USGS); S. J. Lambert (SLA); D. G. Brookins (UNM)

5. TITLE: Effect of Depth on Ground Motion $\$$ 0

OBJECTIVE: To analytically predict subsurface ground motions necessary for the seismic design of underground repository 
facilities and compare these predictions with field measurements.

PARTICIPANTS: D. M. Ellett, L. J. Vortman, SLA

6. TITLE: Subsurface Earthquake Damage $\quad \$ 80$

OBJECTIVE: To determine whether damage from an earthquake is less at depth than it is on the surface and to develop mathematical models.

PARTICIPANT: I. Wende11 Marine, SRL

7. TITLE: Assessment of Geothermal and Volcanic Activity of the Columbia Plateau

OBJECTIVE: To assess the possibility of future volcanic activity in the respository area which could affect the repository. As part of this study, determine the geothermal gradient in the repository area and determine the relationship between past volcanic activity and tectonic structures.

PARTICIPANTS: RHO; Fugro, Incorporated

8. TITLE: Evaluation of Tectonic, Seismic, and Volcanic Hazards, Nevada Test Site and Vicinity $\$ 800$

OBJECTIVE: To assess the potentials for volcanic eruptions, fault movements, regional uplift, erosion, and natural seismicity in the vicinity of the Nevada Test Site.

PARTICIPANTS: W. J. Carr, A. M. Rogers (USGS); B. M. Crowe (LASL)

9. TITLE: Tectonic Stability--Magnetic Anomaly $\$$

OBJECTIVE: To determine the presence/absence of magnetic anomalies in the WIPP site area normally associated with igneous intrusions about 9 miles northwest of the WIPP site; and to determine empirically the magnetic signature, if any, associated with so-called breccia pipes.

PARTICIPANTS: SLA; Undetermined 
10. TITLE:

OBJECTIVE:

Tectonic Stability--Remote Sensing

$\$$

0

To detect and evaluate large, but perhaps subtle, tectonic features that may affect tectonic stability of the WIPP.

PARTICIPANTS: SLA; Undetermined
11. TITLE: Tectonic Stability--Quaternary Fault Mapping $\$ 0$
OBJECTIVE: To provide field evidence on existing faults or areas of interest for mechanism, ages, and magnitudes of movement for assessment of tectonic stability of the Delaware Basin.

PARTICIPANTS: G. 0 . Bachman (USGS), SLA

12. TITLE:

Tectonic Stability--Earthquake Activity

$\$ 175$

OBJECTIVE: To provide reliable estimates of present earthquake activity around the WIPP site for facility design and assessment of long-term tectonic stability.

PARTICIPANTS: A. M. Rogers (USGS); G. R. Keller (UTEP); A. R. Sanford (NMIMT)

13. TITLE: Tectonic Stability--In Situ Stress, Delaware Basin

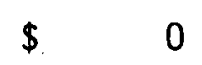

OBJECTIVE: To measure in situ stress to determine whether stress is consistent with the tectonic situation in the northern Delaware Basin; and to determine in situ stress in deformed evaporite sequence.

PARTICIPANTS: SLA; D. W. Powers; R. D. Statler

14. TITLE: Climatic Stability/Tectonic Stability-West Texas Salt Flats Graben

$\$ 25$

OBJECTIVE: To obtain supplementary time/climatic relationships for southeastern New Mexico; and to obtain structural/age relationships for the tilting of the Delaware Basin.

PARTICIPANTS: SLA; D. W. Powers, S. J. Lambert 
15. TITLE: Climatic Stability--Pecos River History $\$ \quad 0$

OBJECTIVE: To determine climatic history of the area during the Quaternary including rates, chronology, and limits of effects.

PARTICIPANT: USGS; G. O. Bachman

16. TITLE: Climatic Stability--San Simon Sink $\$ 0$ OBJECTIVE: To obtain climatic/age information related to periods of dissolution by study of a core of fill material in the San Simon Sink.

PARTICIPANT: SLA; Roger $Y$. Anderson

17. TITLE: $\quad$ Effects of Far-Field Inhomogeneities $\quad \$ 64$

OBJECTIVE: To investigate by use of scaled laboratory models and by analytical techniques the effects of far-field inhomogeneities on heat transfer.

PARTICIPANT: OSU; F. A. Kulacki

18. TITLE: Large-Scale Ground Movements $\$ 100$

OBJECTIVE: To test long-term far-field models.

PARTICIPANT: To be determined

19. TITLE: Natural Fission Reactor Program, OK10 $\quad \$ 350$

OBJECTIVE: To identify the migration paths of some of the mobile fission products and reconstruct the paleohydrology and transport history.

PARTICIPANT: LASL; George Cowan

20. TITLE: Study of the Morro do Ferro Thorium Deposit $\$ 100$ OBJECTIVE: To measure the initial dissolution, subsequent transport, and dispersion of thorium from the Morro do Ferro deposit in the Pocos de Caldas plateau in Minas Gerais, Brazil.

PARTICIPANT: NYU; Merril Eisenbud 
21. TITLE: Field Investigations to Determine In Situ Geologic, Hydrologic, and Engineering Parameters

OBJECTIVE: To provide field services as required to obtain subsurface geologic, hydrologic, and engineering data in support of candidate site selection and evaluation for construction of a nuclear waste repository in Columbia River basalts.

PARTICIPANTS: RHO; PNL; Boyles Brothers Drilling Company; Exploration Data Consul tants; SAI; LBL; Hatch Drilling Co.; Birdwell; Geochron; University of Miami; and J. A. Jones Construction Company

22. TITLE: Waste Rock Interaction Technology: Geochemistry

OBJECTIVE: To determine radionuclide sorption processes under conditions of all candidate repository geologies.

PARTICIPANT: PNL; R. J. Serne

23. TITLE: Geochemical Studies for Nuclide Migration (WIPP)

OBJECTIVE: To determine sorptive capacities for radionuclides in rock/solution systems of southeastern New Mexico and perform assessment of radionuclide migration modeling.

PARTICIPANTS: SLA; D. R. Fortney; R. G. Dosch

24. TITLE: $\quad$ Organic Compounds in Ground Water $\$ 100$

OBJECTIVE: To evaluate the structure and extent of natural organics that may be present in repository environments and analyze potential effects on radionuclide migration.

PARTICIPANT: BCL; J. L. Means

25. TITLE: Ground-water Dating $\$ 225$

OBJECTIVE: To develop methods of dating ground water that is older than 50,000 years. This capability would provide information on past rates of ground-water flow in the vicinity of a repository and aid in verification of predictive models used for determining future rates of ground-water flow.

PARTICIPANTS: I. Wendell Marine (SRL); Stan Davis (University of Arizona); John Apps (LBL) 
26. TITLE: Characterization of Southeastern New Mexico Rocks and Waters

OBJECTIVE: To obtain basic geochemical data on subsurface materials in southeastern New Mexico for brine migration, radionuclide sorption, and borehole plugging studies and to determine the history of rock/solution interaction.

PARTICIPANT: SLA; S. J. Lambert

27. TITLE: Chemical Environment Modeling \$ 266

OBJECTIVE: To characterize the chemical environment in the vicinity of the buried waste packages as a function of time.

PARTICIPANTS: RHO; LBL

28. TITLE: Development of Fracture Flow and ThermalHydraulic Fl ow Models

OBJECTIVE: To review the state of the art of ground-water flow modeling in fractured media; and to determine where emphasis should be placed on future model development; to develop, in parallel, techniques for determining global parameters from borehole data in fractured media and the effects of fracture continuity on these parameters; and to develop and verify fracture flow models that include the effects of temperature on the flow.

PARTICIPANT: Paul Witherspoon (LBL)

29. TITLE: Development of Analytical Transport Models $\$ 150$

OBJECTIVE: To provide an analytical standards capability for the calculation of radionuclide transport in porous media and apply it in support of the performance assessment activities of the NWTS Program.

PARTICIPANT: Thomas Pigford (LBL).

30. TITLE: Brine Migration Modeling $\$ 115$

OBJECTIVE: To develop a comprehensive model of brine migration in ife natural rock salt.

PARTICIPANTS: Don 01 ander (UCB); others to be determined 
31. TITLE: Tracer Tests of Overlying Strata $\quad \$ 50$

OBJECTIVE: To determine permeability and dispersion coefficients of water-bearing rocks overlying evaporites for input of numerical results to radionuclide migration modeling.

PARTICIPANT: D. D. Gonzales (SLA)

32. TITLE: Osmotic Effects of Clay Minerals $\$ 175$

OBJECTIVE: To determine the effects that natural clay membranes can have on pressure.

PARTICIPANTS: I. Wende11 Marine (SRL)

33. TITLE: Systematic Comprehensive Evaluation of Performance and Total Effectiveness of Repositories

OBJECTIVE: To develop, integrate and apply modeling technology to evaluate nuclear waste isolation system performance (both near- and far-field).

PARTICIPANT: R. B. Lantz (INTERA)

34. TITLE: Advanced Evaluation of Geologic Isolation Systems

OBJECTIVE: To develop and apply release scenario and consequence analysis methodology for assessment of repository performance.

PARTICIPANT: Mark Harwell (PNL)

35. TITLE: Nuclear Waste Repository Safety Assessment $\$ 500$

OBJECTIVE: To provide a WIPP site-specific assessment of the longrange consequences of the emplacement of nuclear wastes in the Salado salt formation. The assessment will be dependent on repository design, WIPP site geology and hydrology, waste form, and waste mixes.

PARTICIPANTS: J. P. Brannen (SLA); M. S. Tierney (SLA) 
36. TITLE:

Systems Study of Engineered Barriers

$\$ 450$

OBJECTIVE: To provide a technical basis for decisions regarding the development of engineered barriers for the geologic disposal of spent fuel.

PARTICIPANTS: M. 0. Cloninger (PNL); D. H. Lester (SAI)

37. TITLE: Radionuclide Transport $\quad \$ \quad 0$

OBJECTIVE: $\quad$ To couple source--term assumptions into models for radionuclide movement in the WIPP environment.

PARTICIPANT: J. P. Brannen (SLA)

38. TITLE: $\quad$ Software Support $\quad \$ \quad 0$

OBJECTIVE: To quantify consequences of various source-term assumptions for radionuclide release.

PARTICIPANT: J.P. Brannen (SLA)

39. TITLE: $\quad$ Source Term--Direct Access $\quad \$ \quad 0$

OBJECTIVE: To characterize radionuclide source terms for hypothetical direct-access scenarios.

PARTICIPANT: J.P. Brannen (SIA) 
E. COORDINATION AND REVIEW

1. TITLE: Coordination and Consultation

$\$ 60$

OBJECTIVE: $\quad$ To provide coordination of USGS projects and to provide geological assistance to DOE in lieu of staffing.

PARTICIPANT: G. D. DeBuchananne (USGS)

2. TITLE: Technical Integration and Support

OBJECTIVE: To provide technical support to ONWI in a broad range of areas relating to geologic disposal and to coordinate all ONWI work at ORNL.

PARTICIPANT: A. L. LottS (ORNL)

3. TITLE: Nevada Nuclear Waste Storage Investigations

(NNWSI) Technical Project Coordination \$1,010

OBJECTIVE: To provide coordination and integration of NNWSI technical investigations; to assure appropriate exchange of information among NNWSI contractors; to exchange information with other aspects of the NWTS Program; and to advise DOE on the technical merits of investigative activities in terms of progress toward a capability for repository construction.

PARTICIPANTS: R. C. Lincoln, L. D. Tyler (SLA); W. S. Twenjofel, G. L. Dixon (USGS); K. Wolfsberg, B. M. Crowe (LASL); L. D. Ramspott (LLL) 


\section{NUCLEAR ENERGY \\ OFFICE OF URANIUM ENRICHMENT AND ASSESSMENT}

Estimates of U.S. uranium ore reserves and uranium supply have been made by the Atomic Energy Commission (AEC) and its successors, ERDA, and DOE, since 1952. In response to concerns regarding the adequacy and availability of domestic resources to support extended development of nuclear power in the U.S., and to ensure a sound information base on which federal planning and policy decisions could be based, an expanded effort to systematically assess the nation's potential uranium resources was initiated in 1974.

The goals of the Uranium Resource Assessment program have been to assess and expand the nuclear fuel resource base of the United States; reduce uncertainties regarding economics and availability of domestic and foreign nuclear fuel resources; and make available to industry resource information and technology for use in the discovery and production of uranium resources.

In October 1980 "An Assessment Report on Uranium in the United States" was published covering the highest priority areas containing all of the known reserves and most of the probable potential resources. An improving resource situation, as indicated in this report, and reduced demand projections have mitigated the perceived need for completion of the comprehensive, systematic, nationwide assessment. Consequently, activities designed to increase the data base for resource estimation or to develop advanced technologies for resource identification and assessment are being phased out. Reserve estimation and supply analys is efforts based largely on data furnished by industry will continue much as it has since 1952. Total budget authority is expected to decrease from $\$ 61.5$ million in FY 1980 to $\$ 10.0$ million in FY 1982 . The table of Operating Costs provides an indication of the categories of and expenditures for geoscience related research conducted in FY 1980.

The data base and technology developed by this program over the past five years should serve the nation well for many years, providing a sound factual bas is for future exploration and evaluation of uranium as well as other mineral resources. Of particular significance are the multi-element analyses of hydrologic and stream sediment samples covering some 67 percent of the conterminous U.S. and 82 percent of Alaska, as well as the airborne radiometric and magnetic surveys covering virtually the entire conterminous U.S. and 75 percent of Alaska. Discussions have been held with the U.S. Department of Interior and seminars are being presented to industry and the public to increase awareness of the available data base, clarify what remains to be done and how it may be accomplished.: The table of Selected Projects provides a brief description of topical and technology based projects that were conducted in FY 1980. 
OFFICE OF URANIUM ENRICHMENT AND ASSESSMENT

GEOSCIENCE RELATED RESEARCH

FY 1980 OPERATING COSTS

Project Category

- Geologic and Related Investigations

- Surface

- Aerial

Survey

Technology

- Hydrogeochemical

- Subsurface

Drilling and Logging

Logging only

- Technology Applications

- Technology Development and Evaluation

- Technology Integration
( $\$$ in Millions)

Subcontracts National Labs BFEC I/ USGS Total

$\begin{array}{lcccr}\$ 4.8 & \$ 0.6 & \$ 10.8 & \$ 2.2 & \$ 18.4 \\ 7.9 & - & - & - & 7.9 \\ 0.5 & - & 0.2 & - & 0.7 \\ 0.1 & 10.0 & 0.2 & - & 10.3 \\ 2.8 & - & 1.1 & 0.1 & 4.0 \\ 3.5 & - & 1.3 & - & 4.8\end{array}$

$\begin{array}{rrrrr}0.4 & 1.0 & 2.0 & - & 3.4 \\ 0.3 & \frac{-}{\$ 11.6} & \frac{0.5}{\$ 16.1} & \$ 2.3 & \$ 50.3\end{array}$

1/ Bendix Field Engineering Corporation, Prime Contractor, Grand Junction, Co. 


\section{OFFICE OF URANIUM ENRICHMENT AND ASSESSMENT \\ GEOSCIENCE RELATED RESEARCH \\ SELECTED PROJECTS - FY 1980}

\section{Topical Studies}

1. Title: Uranium Distribution in Fluorine-enriched Volcanic Rocks

Authorized Expenditure: $\$ 79,000$

Contractor: Arizona State University

Principal Investigator: Dr. D. M. Burt

Project Summary: The dynamics of the uranium-fluorine relationship during magmatic differentiation; eruption, welding, secondary crystallization and diagenesis of tuff sheets; and hydrothermal fluid migration were studied. The primary study area was the Spor Mountain-Thomas Range area of western Utah.

2. Title: Study of Uranium and Thorium Potential in Red Muds

Authorized Expenditure: $\$ 55,000$

Contractor: Zellars-Williams

Principal Investigator: Michael E. Zellars

Project Summary: The red mud residues from aluminum production were analyzed for uraniun content. The results indicate that the residues are a potential low- to intermediate-grade uranium resource.

3. Title: NURE Geostatistical Evaluation Study-Phase I

Authorized Expenditure: $\$ 70,000$

Contractor: Terradata

Principal Investigator: C. Kendal1

Project Summary: The current resource assessment methodology was examined from a statistical viewpoint and an in-depth study of control-area parameters to provide a population data set for control areas was made.

4. Title: Uranium in Carbonatites in the United States

Authorized Expenditure: $\$ 93,000$

Contractor: Powell and Associates

Principal Investigator: J. D. Powe11

Project Summary: Genetic models for uranium in carbonatites using world-wide geologic, geochemical, and geophysical data from carbonatites and associated alkaline rocks were prepared. These models were used in evaluating uranium potential of se1ected carbonatites in the United States. 
5. Title: Basin and Range Volcanic Census

Authorized Expenditure: $\$ 80,000$

Contractor: U.S. Geological Survey

Principal Investigator: Karen Wenrich-Verbeek

Project Summary: A compilation and an analysis of past and current USGS geochemical sampling of volcanic rocks in the Basin and Range relating geochemistry to volcanic environments are being made.

\section{Aerial Technology}

1. Title: Spectrum Enhancement-Phase III

Authorized Expenditure: $\$ 320,000$

Contractor: Science Applications, Inc.

Principal Investigator: Dr. John Reed

Project Summary: This is the third phase of a study to demonstrate the applicability of the spectrum-enhancement technique (MAZE) to data acquired with sodium iodide detector systems currently used in aerial radiometric surveys.

2. Title: Reconnaissance Magnetics Interpretation Survey

Authorized Expenditure: $\$ 58,000$

Contractor: QEB, Inc.

Principal Investigator: D. P. O'Brien

Project Summary: The usefulness of combining magnetic data from the NURE surveys with available gravimetric data to provide a more complete regional subsurface interpretation for possible use in evaluating uranium resource potential was studied.

3. Title: Dynamic Test Range-I, Follow-on

Authorized Expenditure: $\$ 110,000$

Contractor: LKB Resources, Inc.

Principal Investigator: R. L. Summerfelt

Project Sumnary: Detailed radiometric and aeromagnetic data were obtained. Contour maps were prepared which allowed users to find both altitude - and location-dependent concentration variations and apply this information to improve airborne calibration coefficients.

4. Title: Vertical Radon Propagation

Authorized Expenditure: $\$ 169,000$

Contractor: Radiation Research Associates, Inc.

Principal Investigator: M. B. Wells

Project Summary: This project furnished much needed information for developing more accurate techniques to account for the distribution of radon daughters and for improving subsequent model calculations. 
5. Title: Phoswich Detector

Authorized Expenditure: $\$ 170,000$

Contractor: Grumman Aerospace Corporation

Principal Investigator: Dr. E. Schneid

Project Summary: Grumman Aerospace fabricated a hybrid Phoswich detector having a greater sensitivity for uranium than a sodium iodide detector by about 50 percent for equal volume or weight systems.

6. Title: Solid State Photomultiplier Tube Applications

Authorized Expenditure: $\$ 70,000$

Contractor: Science Applications, Inc.

Principal Investigator: Raulf Polichar

Project Summary: Conventional spectral-scintillation-type uranium exploration systems are limited to a large extent by undesirable characteristics inherent to the use of the photomultiplier tube. Four tubes were fabricated, and the energy resolution of the prototypes was equal to conventional tubes and the performance of the tubes was potentially superior in use in terms of temperature, voltage, and power consumption.

7. Title: Science Applications, Inc., MAZE Code

Authorized Expenditure: $\$ 223,000$

Contractor: Science Applications, Inc.

Principal Investigator: Dr. Glen Reynolds

Project Summary: The MAZE code study included: the final development and demonstration of a temporal filtering technique conceptually developed under the Spectrum Enhancement Phase II project, and the assembling of computer codes for determining detector response functions of typical aerial radiometric detectors into a user's-oriented package.

\section{Title: Airborne EM Evaluation}

Authorized Expenditure: $\$ 76,000$

Contractor: Geoterrex Ltd.

Principal Investigator: Johin Devalk

Project Sumary: A study to evaluate the effectiveness of the Barringer INPUT System to map resistivity of the sedimentary environments of the Red Desert, Wyoming, Technology Integration site and the Powder River Basin, Wyoming, study areas was undertaken. Results from both study areas indicate that the INPUT system was able to map gross variations of the subsurface resistivity structure but was not sufficiently detailed to map stream channels. 
Technology Development and Evaluation

1. Title: Optical Fiber Logging Cable Development

Authorized Expenditure: $\$ 90,000$

Contractor: Optelecom, Inc.

Principal Investigator: Gordon Gould

Project Summary: An optical fiber logging cable to increase the data transmission capabilities of logging systems many times over industry's standard four-conductor logging cable was studied. The fabricated prototype cable was tested and proved to be feasible for borehole logging.

2. Title: Uranium Borehole Logging with PFN

Authorized Expenditure: $\$ 316,000$

Contractor: Sandia Laboratories

Principal Investigator: Hugh Bivens

Project Summary: Two major areas were investigated: commercialization of the neutron generating tube technology and prompt fission neutron system refinement. Field work was conducted in Texas, New Mexico, and Washington.

3. Title: ${ }^{252}$ Cf-based Direct Uranium Logging System-Phase II

Authorized Expenditure: $\$ 531,000$

Contractor: IRT Corporation

Principal Investigator: Dr. D. K. Steinman

Project Summary: Phase II work was to complete the upgrading of the ${ }^{252} \mathrm{Cf}$-based delayed fission neutron probe built for DOE and certain components of the computer-based system within a logging vehicle. Field work was conducted in Texas, Wyoming, and Washington.

4. Title: Associated Uranium Minerals Logging

Authorized Expenditure: $\$ 361,000$

Contractor: Sandia Laboratories

Principal Investigator: Hugh Bivens

Project Sumnary: This study is investigating the development of a gamma-ray spectroanalysis probe that assays for elements which are associated with uranium deposits. It is envisaged that this probe, when developed, will be used with other prospecting techniques in a systems approach for the identification of $U$ mineralization.

5. Title: Borehole Neutron Correlation-Phase II

Authorized Expenditure: $\$ 69,000$

Contractor: Consolidated Controls Corporation

Principal Investigator: C. W. Peters

Project Summary: Experiments were conducted to test the associated particle technique for uranium exploration with probes containing neutron generators. The results were used to test theoretical calculations from Phase I of the project. 
5. Title: Ganma-ganma Transport Calculations-Phase I and Phase II

Authorized Expenditure: $\$ 120,000$

Contractor: Science Applications, Inc.

Principal Investigator: W. A. Woolsen

Project Summary: This study investigated the gamma-ray backscatter principle as a direct uranium logging method. The study also determined the sensitivity of formation density measurements to variations in borehole diameter, fluid, rugosity, and mud cake conditions, and detemined probe design parameters.

; Title: Computation and Non-destructive Assay Methods

Authorized Expenditure: $\$ 270,000$

Contractor: Los Alamos Scientific Laboratory

Principal Investigator: Michael Evans

Project Sumary: Camma-ray flux calculations for infinite homogeneous rock media were developed.

8. Title: Borehole Data Acquisition and Transportation System (BDATS)

Authorized Expenditure: $\$ 100,000$

Contractor: Science Applications, Inc.

Principal Investigator: Robert Hancock

Project Sumary: This contract provided for the construction of a prototype BDATS that utilized digital data transmission and acquisition techniques.

9. Title: $\mathrm{He}^{4} / \mathrm{Ar}^{36}$ Ratio and ${ }^{222} \mathrm{Rn}$ Measurements

Authorized Expenditure: $\$ 143,000$

Contractor: Teledyne Isotopes

Principal Investigator: Dr. Don Shultz

Project Sumary: The project included sampling areas of known

mineralization in Red Desert, Wyoming; Copper Mountain, Wyoming;

and Spokane Mountain, Washington. Results indicated that the $\mathrm{He}^{4} / \mathrm{Ar}^{36}$ ratio did elininate the problem of local variation in soil-gas, values.

10. Title: Uranium Isotopes Studies-Phase II

Authorized Expenditure: $\$ 62,000$

Contractor: Florida State University

Principal Investigator: J. K. Osmond

Project Summary: Phase II involved an in-depth evaluation

with ground-water samples from deep holes in the Grants mineral

belt, New Mexico. 
11. Title: Lead Isotopes in Ground Water

Authorized Expenditure: $\$ 52,000$

Contractor: California State University at Los Angeles

Principal Investigator: Dr. T. E. Davis

Project Summary: This project studied the U/Pb variations in and around known mineralization for uranium deposit haloidentification studies. Ground water samples were collected at different levels from seven BFEC/DOE holes and from leaching the core samples collected at the same site.

12. Title: Uranium and Radon Daughters by Nuclear Emulsions

Authorized Expenditure: $\$ 51,000$

Contractor: Stieff Research and Development Co., Inc.

Principal Investigator: Lorin Stieff

Project Summary: The major objective of the study was to obtain data on the systematic distribution and concentration of $238 \mathrm{U}$ and its daughter products $226 \mathrm{Ra}, 210 \mathrm{~Pb}$, and $234 \mathrm{U}$ from drillhole and geochemical samples collected over or near known orebodies via nuclear emulsion techniques and to determine whether leachable $210 \mathrm{~Pb}$ values represent an enhanced $222 \mathrm{Rn}$ signal.

13. Title: Delayed Neutron Logging Demonstration

Authorized Expenditure: $\$ 120,000$

Contractor: IRT Corporation

Principal Investigator: Dr. D. K. Steinman

Project Summary: The objective of the project is to evaluate the ${ }^{252}$ Cf logging probe (DFN).

Technology Integration

\section{Title: Stable Isotope Ratios}

Authorized Expenditure: $\$ 94,000$

Contractor: Global Geochemistry Corporation

Principal Investigator: Dr. I. R. Kaplan

Project Summary: These studies delineated halos around known uranium deposits, and exploration models will be prepared.

2. Title: Seismic Reflection Applications

Authorized Expenditure: $\$ 118,000$

Contractor: Geophysical Services, Inc.

Principal Investigator: Richard Maxwe1l

Project Summary: This work will investigate the subsurface lithology and structure of the Westwater Canyon Member of the Jurassic Morrison Formation in the San Juan Basin near Crown Point, New Mexico. 
The role of the Department of Energy in defense activities is to provide for national security requirements in support of the Department of Defense and includes a wide range of programs. The Assistant Secretary for Defense Programs directs the Nation's nuclear weapons research, development, testing, production, and stockpile surveillance program. In addition, the Assistant Secretary coordinates a safeguards and security program related to facilities and to the provision of accountability and physical protection of special nuclear materials. Further responsibilities include management of the inertial fusion development and nuclear materials production programs, classification and declassification of nuclear weapons information, and analysis and coordination of international activities related to nuclear technology and materials. 
The Office of Military Application (OMA), under the Assistant Secretary for Defense Programs, directs the research, development, engineering, testing, and production of all U.S. nuclear weapons; maintenance of reliable weapons for their stockpile life; and retirement and disposal of nuclear weapons from the stockpile. Weapon research and development is conducted primarily at the Department of Energy's three nuclear weapon laboratories: Lawrence Livermore National Laboratory (LLNL), Livermore, California, Los Alamos National Laboratory (LANL), LoS Alamos, New Mexico; and Sandia National Laboratories at Albuquerque, New Mexico (SNLA), and Livermore, California (SNLL). Underground nuclear testing is conducted at the Nevada Test Site (NTS). Weapons production is conducted at seven government-owned, contractor-operated plants.

A major objective of the geosciences research and development efforts is to assure that the U.S. nuclear test program is conducted safely with respect to effects on man, structures, and the environment. Much of this work is performed by a variety of specialized contractors under the auspices of the Department of Energy's (DOE) Nevada Operations Office. The weapons laboratories also perform geosciences research in selected disciplines. Principal areas of interest include:

1. Geology/Hydrology--studies of rock formations and properties; distribution and circulation of water in the soil and underlying rocks in proposed underground test areas;

2. Seismology--development of reliable ground motion prediction techniques; measurement and evaluation of ground motion during NTS events; measurements of the response of structures to ground motion produced by underground nuclear tests; and investigations to improve U.S. capability to detect, locate, and identify nuclear explosions;

3. Radionuclide Migration Studies--study movement of explosive-produced radionuclides in the subsurface away from test sites;

4. Atmospheric Sciences--studies of fallout models, radiation models, trajectory predictions, and long-range diffusion studies; studies of airglow, aurora, cosmic rays, atmospheric aerosols, and dynamic interaction of plasmas with the upper atmosphere; pollutant transport theory; climate modeling; and composition of the atmosphere.

The total OMA program in environmental sciences which includes all geosciences activities was estimated at \$6.6M in FY 1980. 
Title:

Budget:

Principal Investigator:
Rock Deformation and Failure $200 K$

B. M. Butcher (SNL)

Summary: Experimental studies are supporting model development for computer codes describing the static and dynamic deformation and failure of competent rock, deformation of joint systems and rock fragmentation.

Title:

Budget:

Principal Investigator:
Containment studies

$450 \mathrm{~K}$

C. W. Smith (SNL)

Summary: Examination of phenomenology of residual stressfields by measurements on nuclear and high explosive events. In G-tunnel at NTS, fractures are being driven into tuff with air and water. Air fracture measurements pertain to the propagation of steam hydrofracs; water fracture measurements, plus analysis, yiela estimates of in-situ stress fields.

Title:

Budget:

Principal Investigator:
On-site Ground Motion from Underground $70 \mathrm{~K}$

\section{IOK} Weapons Tests

Summary: Prediction, measurement, and evaluation of ground motion during Nevada Test Site events, with special emphases on the compatibility between weapon testing and Nevada Nuclear waste Storage investigations and on containment diagnostics. Some comparisons with earthquake motion are included.

Title:

Budget:

Principal Investigator:
Sandia Seismic Net $270 \mathrm{~K}$

H. D. Garbin and L. R. Hill (SNL)

Summary: Seismic stations placed around the Nevada Test Site are used to determine yields of underground nuclear tests and obtain earthquake/explosion discrimination data.

Title:

Terradynamic Soil and Rock Penetration Program

Budget: $1900 \mathrm{~K}$

Principal Investigator: C. E. Dalton (SNL)

Summary: Studies of soil and rock penetration by instrumented projectiles. The structural response of the penetrator and target are being investigated both analytically and experimentally at velocities up to $1000 \mathrm{~m} / \mathrm{s}$ into natural targets. Laboratory and modeling efforts involve characterizing the soil and rock physical properties and their contributions to penetration. 
Title:

NV Geology Support

Budget :

$\$ 214 K$

Principal Investigator:

A. T. Fernald, USGS

(303)234-2391

Summary:

1. To provide a senior geology consultant and an alternate member to attend meetings of the Containment Evaluation Panel to evaluate the containment of each nuclear test.

2. To manage a facility at Mercury, Nevada, for the collection of drill cores and cuttings for nuclear weapons programs and radioactive waste management programs.

Title:

Technical Support to LANL

Budget :

$\$ 115 \mathrm{~K}$

Principal Investigator:

E. C. Jenkins, USGS

(303)234-2391

Summary:

To provide the Laboratory with advice on (1) site selection for nuclear tests; (2) lithology and geologic structure; (3) depth to Paleozoic rocks by gravity methods; and (4) presentations by the Laboratory at CEP meetings.

Title:

Technical Support to LLNL

Budget:

$\$ 115 \mathrm{~K}$

Principal Investigator:

E. C. Jenkins, USGS

(303)234-2391

Summary:

To provide the Laboratory with advice on (1) site selection for nuclear tests; (2) lithology and geologic structure; (3) depth to Paleozoic rocks by gravity methods; and (4) presentations by the Laboratory at CEP meetings. 
Title

Budget

Principal Investigators: R. W. Whitaker, E. M. Jones, M. T. Sandford, H. G. Horak

Summary: We model optical signatures from low altitude nuclear weapons using one and two dimensional radiation-hydrodynamic computer codes. We also define the dusty nuclear environment by making significant additions to our two dimensional KFIX and developed a two phase two dimensional radiation version of YAQUI. This enables us to respond to important questions raised by gaps in our understanding of the importance of dust on nuclear effects.

Title Budget Principal Invesgigators: : Improved Geologic Interpretation at NTS Using Electric Logs : $20 \mathrm{~K}$

Summary: We use electric logs, a geophysical tool measuring the resistivity of a rock formation, for detailed geologic interpretation at the Nevada Test Site. Electric logs have successfully been used to identify a missing rock sequence (geologic fault), enhance stratigraphic interpretation and aid in accurate definition of new site selections for future emplacement holes. Objectives are: to aid in the interpretation of seismic data at NTS; use electric log interpretation in new areas considered for underground testing and storage of radioactive waste; and graphically represent this refined geologic data to give a more accurate regional interpretation which would aid both the geologist and nongeologist who is required to understand geologic problems.

Title

Budget

Principal Investigator: T. Dey

Summary: Porosity, permeability, and electrical resistivity of zeolitized and other tuffs are measured and correlated under both hydrostatic and triaxial stress conditions. Archie's law will be tested for its applicability to tuffs. Measurements of these properties, together with stress and strain information for samples loaded to failure, are made simultaneously. The observed phenomena will be used to indicate similarities and differences in failure processes in tuffs compared to sandstones and granites

Title

Budget

: Regional Seismological Research

Principal Investigators: $631 \mathrm{~K}$

K. H. Olsen, J. N. Stewart, E. F. Homuth, C. A. Newton, D. J. Cash

Summary:

We analyze short-period and broadband seismic recordings and infer from them detailed models of crust and upper mantle structure beneath areas of New Mexico, Nevada, Arizona, Midwestern United States, and the U.S.S.R. 
We seek improved diagnostic indicators for discriminating between possibly clandestine low-yield underground nuclear explosions and small earthquakes as observed at regional distance ranges $(200-2000 \mathrm{~km})$. A major analytic procedure is detailed waveform modeling by sophisticated computer programs; extensions and improvement of these synthetic seismogram codes is a major component of the research. Our long-range goal is to obtain important new basic understanding of short-period wave propagation in laterally complex earth structure and improve knowledge of seismogram character at regional distances. 


\section{NEVADA OPERATIONS OFFICE}

Title:

Budget:

Principal Investigator: J. A. Lahoud (Adaptronics, Inc.)

(703) 893-6650

FTS 8-202-893-6650

Summary: A 14-month program to complete the postshot analysis of ground motion data collected during the accelerated high-yield test program at the Nevada Test Site and to update ground motion prediction technology.

Title: $\quad$ Structural Response Studies

Budget: $\quad \$ 561 \mathrm{~K}$

Principal Investigator: K. K. Honda, John A. Blume \& Associates Engineers, Inc., (415) 397-2525

FTS 8-415-397-2525

Summary: A three-year study consisting of four research tasks which deal with these on-going research programs are required to develop and improve these technical methods for prediction of on- and off-site structural damage potential resulting from proposed underground nuclear tests. Tasks include: Structural response analysis (highrise damage criteria), environmental effects studies, low-rise damage analysis, new structural and architectural systems. 
Title:

Budget:

Principal Investigator:
Radionuclide Migration

$\$ 28 \mathrm{~K}$

Paul R. Fenske (DRI) (702) 673-7371

Summary: The Radionuclide Migration Program is a program to investigate radionuclide distribution in rubble chimneys created by underground nuclear tests and the transport of those radionuclides from the rubble chimney by moving groundwater. Field operations involve monitoring and pumping of drill-back holes within and external to rubble chimneys.

Title:

NTS Cultural Resources Management Program

Budget:

$\$ 26 \mathrm{~K}$

Principal Investigator: Lonnie Pippin (DRl) (702) 673-7306

Summary: This program includes two overlapping research activities: (1) the immediate on-call reconnaissance of areas proposed for land disturbing activities by the Department of Energy or its contractors, and (2) the long range, systematic inventory and analyses of archeological records of the Nevada Test Site.

The first activity, required by several federal acts is oriented toward protecting significant archeological resources from adverse and inadvertent impact by the Department of Energy.

The Inventory of Cultural Resources also required by federal legislation is designed to provide information on cultural history, paleoenvironmental variability, prehistoric and historic settlement patterns in relation to land forms and economic resources and ecological and cultural processes which influence these adaptive systems through time. 
Title:

Budget:

Principal Investigator: Stephen Wheatcraft (DRI) (702) 673-7393

Summary: In areas where underground nuclear tests are conducted, knowledge of the groundwater resources is required for the containment, design, assessment of radionuclide transport and development of water supplies. Groundwater resource studies will identify areas of serious data deficiencies and provide a basis for planning supplemental data collection programs.

The first and most easily accomplished task in analyzing the groundwater resources is the construction of a map showing the probable configuration of the water table. The second, and the more difficult step, is the construction of a three dimensional model flow system. Two saturated zone programs are currently underway, an empirical water table mapping program and a numerical analyses program of the three-dimensional aspects at the NTS hydrological system. In addition, the geochemistry of Nevada Test Site waters in wells and springs is being investigated to define the flow systems.

Title: Unsaturated Zone Program

Budget: $\quad \$ 117 \mathrm{~K}$

Principal Investigators: Roger Jacobson (DRI) (702) 673-7373 Clinton M. Case (702) 673-7375

Summary: The regional unsaturated zone programs involve field effort as well as laboratory and theoretical studies on the movement of water and the transport of radionuclides through the unsaturated zone to the water table on the Nevada Test Site. An important part of the field effort has been delineation and study of recharge areas in a desert environment. This study involves a field program that investigates the movement of groundwater through the unsaturated zone both in areas of infiltration and through the thick unsaturated zone above the tunnel complex at Rainier Mesa. The groundwater recharge program currently involves: (1) a study of washes and their importance to recharge in the unsaturated and saturated zones, and (2) a study to address the fundamental recharge on bedrock areas and an attempt to correlate this with water quality changes in the Rainier Mesa tunnels. 
Associated with this will be the monitoring of springs primarily at the base of Rainier Mesa. By determining the quantity and quality of the spring water it is possible to separate base flow from more direct storm waters.

Title:

Budget:

Principal Investigators:
Containment Evaluation Pane!

$\$ 73 \mathrm{~K}$

Paul R. Fenski (DRI) (702) 673-7371

Clinton M. Case (702) 673-7375

Summary: The principal investigators on this project are member and alternate member of the containment evaluation panel for the Department of Energy. Their main task is to review all containment designs for underground nuclear tests and to provide their judgment along with the other panel members on the likelihood of possible venting of radioactivity into the atmosphere. In addition to serving on the panel, a duplicate nuclear event data file is kept in the DOE computer and the DRI members on the containment evaluation panel carry out studies in hydrology and geology as related to containment as necessary.

Title: Radionuclide Transport Assessment at the NTS

Budget: $\$ 70 \mathrm{~K}$

Principal Investigator: Clinton M. Case (DRI) (702) 673-7375

Summary: This program investigates the possible migration of radionuclides away from proposed and currently used disposal locations on the Nevada Test Site. A number of specific activities are required: (1) flash flood investigations, (2) climatic investigations, (3) measurements of existing soil saturation, (4) measurement of soil suction, (5) measurements of the saturated hydrologic conductivity as a function of saturation, (6) measurements of soil water temperatures, and (7) studies of chemical interactions of specific ions with relevant soils. These studies are carried out as field efforts, laboratory efforts and theoretical efforts. 
Title: NV Geology Support

Budget: $\quad \$ 214 \mathrm{~K}$

Principal Investigator: $\quad$ A. T. Fernald (USGS)

(303) 234-2391

Summary: (1) To provide a senior geology consultant and an alternate member to attend meetings of the Containment Evaluation Panel to evaluate the containment of each underground nuclear test. (2) To manage a facility at Mercury, Nevada, for the collection of drill cores and cuttings for nuclear weapons programs, which provides data on a continuing basis on the geology of NTS and other locales.

Title: $\quad$ Radiation Prediction Techniques for Nuclear Test Support

Budget: $\quad \$ 41 \mathrm{~K}$

Principal Investigator: H. F. Mueller (WSNSO)

(702) $734-3513$

Summary: To provide radiation exposure/dose prediction capabilities in support of DOE nuclear test activities. This support function requires continuing development and implementation of radiological prediction methodologies unique to varying test configurations, release modes, and radionuclide inventories. Prediction techniques development involves meteorological and radiological interdisciplinary studies related to the transport, dispersion, and deposition of radioactivity released into the atmosphere and resulting exposures or absorbed doses. Digital computer codes and electronic calculator programs are formulated for some of the prediction techniques employed. 
Title:

Budget:

Principal Investigator:
Meteorology for Ecological Studies

$\$ 18 \mathrm{~K}$

H. F. Mueller (WSNSO)

(702) 734-3513

Summary: Measurement of physical parameters in environmental and ecological studies usually includes the measurement of meteorological variables such as temperature of the air; humidity and solar radiation; measures of air motion or ventilation such as mean wind direction and wind speeds at varying heights above the surface; soil and vegetative surface temperatures; and soil moisture. These types of measurements are made to help in identifying and understanding the routes whereby radioactive materials are redistributed. Currently, the major effort is concentrated on the study of plutonium and certain other radionuclide contamination in the environs of the Nevada Test Site with special emphasis on the resuspension and transport of radioactive material by the wind. A special meteorological measurement network is operated in connection with radiological measurements being made by the Lawrence Livermore Laboratory. Activities are coordinated by the Nevada Applied Ecology Group.

Title: Studies to Improve Weather, Wind, Trajectory, and Transport Prediction for Nuclear Tests

Budget: $\$ 110 \mathrm{~K}$

Principal Investigator: H. F. Mueller (WSNSO) (702) $734-3513$

Summary: Provide the continuing meteorological services required in the safety and technical programs associated with all forms of nuclear and nonnuclear experiments conducted by the DOE Nevada Operations at the Nevada Test Site and other places. Studies are conducted to improve the equipment and procedures for measuring, analyzing, and predicting the atmospheric processes involved in the transport of any radioactive. effluents from nuclear tests. The potential effects of radioactivity on the bioenvironment justifies continuing efforts to understand transport phenomena and predict the areas to be subject to potential exposure. A variety of approaches are used, including statistical relationships, case studies, and dynamical modeling to improve predictions; development of automated telemetered sensors to measure input atmospheric parameters; and development of computer programs to process data, perform calculations, and display results. The 
meteorological studies are based primarily on weather and wind data collected in the process of supporting nuclear tests, but National

Weather Service network data and local measurements are also used. The effluents from past nuclear rocket engine tests, cratering tests, and atmospheric experiments are used to provide large scale transport data. 
Lawrence Livermore National Laboratory

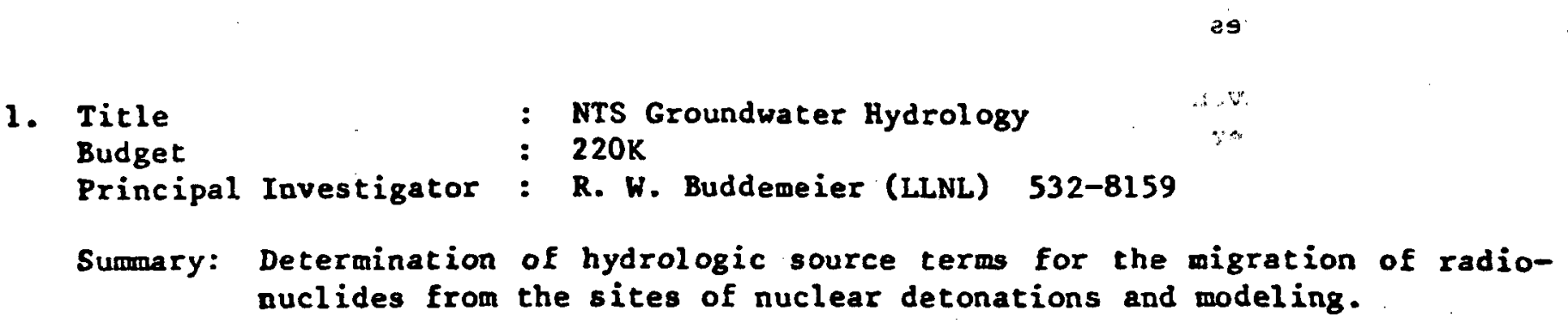

2. Title : Geologic and Geophysical Studies at the Nevada Test

Budget : 200K

Principal Investigator : H. Lawrence McKague (LLNL) 532-6491

Summary: Various geologic projects such as alluvium correlation studies and age dating of carbonate from faults and stratigraphic horizons lead to a better understanding of NTS geology, and concomitantly, the safe and effective use of the NTS.

3. Title : Geologic and Geophysical Characterization of Nuclear Test Sites

Budget $\quad: 500 \mathrm{~K}$

Principal Investigator : N. Howard (LLNL) 532-6491

Summary: Geologic and geophysical descriptions allow site evaluation of containment for proposed underground nuclear tests.

4. Title : Geologic and Nuclear Test Effects Data Base

Budget : 150K

Principal Investigator : N. Howard (LLNL) 532-6491

Sumary: All geologic and nuclear test effects data are entered in a computerized data base so that new sites may be compared and evaluated to previous tests.

5. Title

Budget

: Seismic Surveys at the Nevada Test Site

Principal Investigator : N. Burkhard (LLNL) 532-6483

Summary: Knowledge of the subsurface geology is needed for siting of NTS experiments. Because of the seismic characteristics of the alluvium, conventional seismic surveys have not been effective in defining the subsurface geology. This work has developed successful seismic techniques. 


\section{Title : Improved Geophysical Logging \\ Budget : $\$ 50 \mathrm{~K}$ \\ Principal Investigator : J. Hearst (LLNL) 532-6490}

Sumary: Conventional well logging methods are not satisfactory for determining water and carbonate content at NTS. Special logs and calibration techniques are being developed to solve these and similar problems.

7. Title

Budget

: Containment Studies for Nuclear Weapons Testing

Principal Investigator : R. Terhune (LLNL) 532-3964

Sumary Computer modeling of explosion phenomenology and earth wedia behavior characteristics to develop containment risk analysis procedure for Nuclear Weapons Test Program.

8. Title : Stratospheric Effects of Atmospheric Nuclear Explosives

Budget : 60K

Principal Investigator : F. M. Luther (LLNL) 532-1825

J. S. Chang (LLNL) 532-4081

Sumary: To understand and assess the potential impact of atmospheric nuclear explosives on the stratosphere, ultraviolet radiation flux and surface climate by use of numerical models of the chemistry and physics of the atmosphere.

0419B/0008B 